revista do ieb n 46 p. 81-122 fev 2008

\title{
A "America" de Jodocus Hondius (1563-1612): um estudo das fontes iconográficas
}

\author{
Dante Martins Teixeira ${ }^{1 \text { e } 2}$
}

\section{Resumo}

Entre os quarenta novos mapas compostos por Jodocus Hondius para a edição de 1606 do famoso "Atlas" de MercatorHondius, a "America" desperta particular interesse por ser considerada uma das mais belas cartas jamais impressas sobre o Novo Mundo. Das 17 gravuras decorativas presentes nesse mapa, as cinco mais importantes retratam composições envolvendo habitantes de diferentes partes do mundo, enquanto as demais mostram navios europeus, monstros e animais marinhos. Embora haja uma clara influência das "Grand Voyages" dos De Bry, essas imagens estão baseadas em várias outras publicações dos séculos XVI e XVII, tais como a "Cosmographie Universelle" de André Thevet e o relato de Dionyse Settle sobre a viagem do capitão Martin Frobischer. Apesar de sua complexidade, a "America" talvez mereça ser entendida como um tributo à expansão das forças reformistas em sua feroz disputa pelas fabulosas riquezas do além-mar.

\section{Palavras-chave}

Jodocus Hondius, Mapas, Atas Mercator-Hondius, Cartografia Holandesa, Theodore de Bry, Iconografia.

1 Departamento de Vertebrados, Museu Nacional-UFRJ. Quinta da Boa Vista, Rio de Janeiro (RJ), 20940-040. Bolsista do CNPq.

2 Nossos agradecimentos ao Instituto Cultural Banco Real, São Paulo, pela concessão das imagens referentes aos mapas de Jodocus Hondius, Henricus Hondius e Joannes Janssonius pertencentes à Coleção de Arte ABN AMRO REAL. Durante os estudos prévios e execução desse trabalho, contamos com a valiosa colaboração de Iris Kantor (Faculdade de Filosofia, Letras e Ciências Humanas-USP), Beatriz Siqueira Bueno (Faculdade de Arquitetura e Urbanismo-USP), Maria Carlota Rosa (Faculdade de Letras-UFRJ) e Henrique Fortuna Cairus (Faculdade de Letras-UFRJ), cujos comentários e sugestões 
revista do ieb n 46 p. 81-122 fev 2008

\title{
Jodocus Hondius's America: a study of its iconographic sources
}

\author{
Dante Martins Teixeira
}

\begin{abstract}
Included among the forty new charts composed by Jodocus Hondius for the 1606 issue of the famous "MercatorHondius" Atlas, the "America" is usually considered one of the most splendid maps ever printed about the New World. Of the seventeen ornamental engravings depicted in that map, five compositions are especially significant and show inhabitants from different parts of the world, whereas the remaining twelve represent European ships, sea monsters or marine animals. Despite the well marked influence of the De Bry's "Grand Voyages", several illustrations are based on other sixteenth and seventeenth century works, as the "Cosmographie Universelle" by André Thevet and the Dionyse Settle's report on the voyages of Captain Martin Frobischer. Composing an intricate mosaic, the "America" could be regarded as a tribute to the Protestant expansion in his fierce dispute for the fabulous treasures from overseas.
\end{abstract}

\section{Keywords}

Jodocus Hondius, Maps, "Mercator-Hondius” Series, Dutch Cartography, Theodore de Bry, Iconography.

mostraram-se de grande valia para a compreensão dos originais e para a análise realizada. Cabe agradecer ainda a Paulo Martins Teixeira pela arte final das figuras do texto, bem como a Vera de Figueiredo Barbosa, Antônio Carlos Gomes Lima (Biblioteca do Museu Nacional/UFRJ) e Margareth Elisabeth Cardoso (Livraria Carioca Rio Antigo) pelo auxílio prestado na reunião da bibliografia pertinente e/ou na análise das referências utilizadas. Por fim, cumpre destacar o apoio concedido pelo Conselho Nacional de Desenvolvimento Científico e Tecnológico $(\mathrm{CNPq})$ às pesquisas realizadas pelo autor durante os últimos anos. 
Considerado um dos maiores gravadores de sua época, Jodocus Hondius tornou-se célebre sobretudo pelos trabalhos realizados em parceria com alguns dos melhores cartógrafos e editores existentes no final do século XVI. Tendo nascido em Flandres no ano de 1563, parece ter crescido na próspera cidade de Ghent, onde teria aprendido o ofício de construir instrumentos e globos terrestres, assim como a gravação de mapas. Em 1584, na tentativa de escapar dos conflitos religiosos que então assolavam os Países Baixos, Hondius fixou residência em Londres, travando relações com geógrafos, cientistas e exploradores. Durante sua permanência no país, trabalharia nas lâminas do "Mariners Mirrour" - a edição inglesa do "Spiegel der Zeevaerdt" de Lucas Janszoon Waghenaer ${ }^{3}$ - além de preparar outras cartas com seu cunhado Pieter van den Keere. Por volta de 1593, Hondius voltou para Amsterdam, onde se estabeleceu como impressor e comerciante de mapas ${ }^{4}$.

Em torno de 1604, já como profissional bem sucedido, Jodocus Hondius conseguiu adquirir as matrizes em cobre referentes ao "Atlas" do falecido Gerard Mercator, cuja obra perdera muito espaço frente ao disputado "Theatrum Orbis Terrarum" de Abrahan Ortelius ${ }^{5}$, trabalho que vinha obtendo quase uma tiragem por ano. Na tentativa de reverter essa situação, Hondius acrescentaria 40 novos mapas de sua própria autoria ao elenco original e utilizaria uma variante do texto anterior revista e ampliada por seu cunhado - o geógrafo holandês Petrus Montanus - oferecendo ao público uma nova

3 WAGHENAER, L. J. The Mariners mirrovr wherin may playnly be seen the courses, heights, distances, depths, soundings, flouds and ebs, rising of lands, rocks, sands and shoalds, with the marks for th'entrings of the harbouroughs, havens and ports of the greatest part of Europe. London: John Charlewood, 1588.

4 Para maiores detalhes, vide BROWN, L.A. The story of maps. New York: Bonanza Books, 1949; CROSS, W. R. Dutch cartographers of the seventeenth century. Geographical Review 6 (1): p. 66-70, 1918; KEUNING, J. The Novus Atlas of Johannes Janssonius. Imago Mundi, n. 8, p. 71-98, 1951; MORELAND, C. \& BANNISTER, D. Antique maps. London: Phaidon Press, 1993; TOOLEY, R.V. Maps and map-makers. London: B.T. Batsford, 1949; TOOLEY, R. V. Dictionary of map makers. Tring: Map Collector Publications, 1978.

5 MERCATOR, G. K. Atlas sive Cosmographicae Meditationes de Fabrica Mvndi et Fabricati Figvra. Duisburg: Gerardus Mercator, 1585; ORTELIUS, A. Theatrum Orbis Terrarum. Antverpiae: Egidius Coppens, 1570. 
versão do antigo "Atlas" dois anos mais tarde ${ }^{6}$. Pertencente à chamada "Série Mercator-Hondius"7, essa publicação ganharia mais três edições latinas e uma francesa entre 1607 e 1611. Com o passamento de Jodocus Hondius em 1612, a viúva continuou a imprimir esse novo "Atlas" sob o nome de seu finado marido, trazendo à luz outras quatro tiragens latinas e duas francesas entre 1612 e 1619. A partir de então, o "Atlas" prosseguiria sob a responsabilidade de Henricus Hondius, o segundo filho do casal, que assinou uma edição francesa e duas latinas lançadas nos oito anos seguintes. A esse esforço viria somar-se Joannes Janssonius, o qual havia desposado Elisabeth Hondius em 1612, fixando-se em Amsterdam como livreiro.

Conforme seria de esperar, Joannes Janssonius logo se envolveu com a cartografia, publicando os primeiros mapas em 1616. Entre 1630 e 1638, Janssonius estabeleceria uma parceria com seu cunhado Henricus para promover novas edições do "Atlas" de Mercator-Hondius - a famosa "Série Mercator-Hondius-Janssonius”. Em 1639, logo após a morte de Henricus, essa obra foi reformulada por Janssonius no chamado "Atlas Novus", processo que levaria à substituição de pranchas tais como a "America" - uma das cartas elaboradas por Jodocus Hondius para o "Atlas" de $1606^{8}$.

Constituindo um verdadeiro amálgama de diferentes fontes cartográficas ${ }^{9}$, a "America" de Hondius alcançaria grande notoriedade por seu indiscutivel valor estético, sendo

6 MERCATOR, G. K. \& HONDIUS, J. Atlas sive Cosmographicae Meditationes de Fabrica Mvndi et Fabricati Figvra. Amsterodami: Jodocus Hondius, 1606.

7 Sensu MORELAND, C. \& BANNISTER, D. Antique maps. London: Phaidon Press, 1993.

8 BURDEN, P. D. The mapping of North America: a list of printed maps 15111670. Rickmansworth: Raleigh Publications, 1966; CROSS, W.R. Dutch cartographers of the seventeenth century. Geographical Review, n. 6 (1), p. 66-70, 1918; KEUNING, J. The history of an atlas: Mercator-Hondius. Imago Mundi, n. 4, p. 37-62, 1947; KEUNING, J. The novus atlas of Johannes Janssonius. Imago Mundi, n. 8, p. 71-98, 1951; KOEMAN, C. Atlantes Neerlandici: bibliography of terrestrial, maritime and celestial atlases and pilot books published in the Netherlands up to 1880. Amsterdam: Theatrum Orbis Terrarum, 1967; KROGT, P. van der. Amsterdam atlas production in the 1630s: a bibliographer's nightmare. Imago Mundi, n. 48, p. 149-160, 1996; MORELAND, C. \& BANNISTER, D. op.cit.; TOOLEY, R. V. Maps and mapmakers. London: B.T. Batsford, 1949.

9 BURDEN, P. D. op.cit.; WAGNER, H. R. The cartography of the Northwest Coast of America to the year 1800. Mansfield: Martino Fine Books, 1937. 
considerada uma das mais belas representações geográficas do continente jamais impressas (Fig. 1). Na opinião de certos autores, as vistosas cenas figuradas teriam sido extraídas das célebres "Grand Voyages" de Theodore de Bry e de seus sucessores, proposta necessariamente limitada às nove partes publicadas antes de $1606^{10}$. Malgrado a coletânea dos De Bry

10 Semelhante opinião encontra-se bem exemplificada por BURDEN, P. D. The mapping of North America: a list of printed maps 1511-1670. Rickmansworth: Raleigh Publications, 1966. Tais autores necessariamente pretendem referir-se aos nove primeiros volumes das "Grand Voyages", ou seja: DE BRY, T. Admiranda Narratio fida tamen, de commodis et incolarvm ritibvs Virginiae, nvper admodvm ab anglis, qvi à Dn. Richardo Greinville eqvestris ordines viro è in colonian Anno M.D.LXXXV dedvcti sunt inventae, svmtvs faciente Dn. Waltero Raleigh eqvestris ordinis viro fodinarv stanii praefecto ex avctoritate Serenissima Reginae Angliae. Francoforti ad Moenvm: Typis Ioannis Wecheli, 1590; DE BRY, T. Indorvm Floridam provinciam inhabitantium eicones, primùm ibidem ad vivum expressae à Iacobo le Moyne cui cognomen De Morgves: addita ad singulas brevi earum declaratione. Francoforti ad Moenvm: Typis Ioãnis Wecheli, 1591; DE BRY, T. Americae Tertia Pars. Memorabile Provinciae Brasiliae Historiam continẽs, germanico primium sermone scriptam à Ioãne Stadio Homburgensi Helso, nunc autem latinitate donatam à Teucrio Annaeo Priuato Colchante Po: \& Med: Addita est Narratio profectionis Ioannis Lerij in eamdem Provinciam, quã ille initio gallicè conscripsit, postea verò Latinam fecit. Francofurte: Theodori de Bry, 1592; DE BRY, T. Americae Pars Qvarta. Sive, Insignis \& Admiranda Historia de reperta primùm Occidentali India à Christophoro Columbo Anno M.CCCCXCII Scripta ab Hieronymo Bezono Mediolanense, qui istic ãnis XIIII versatus, diligẽter omnia observavit. Francofurte: Theodoro de Bry, 1594; DE BRY, T. Americae Pars Qvinta. Nobilis \& admiratione plena Hieronymi Benzoni Mediolanensis, secunda sectionis. Francofurte: Theodoro de Bry, 1595; DE BRY, T. Americae Pars Sexta. Sive Historiae ab Hieronymo Bẽzono Mediolanẽse scriptae, sectio tertia, res nõminus nobiles \& admiratione plenas continens, quàm praecedentes duae. Francofurte: Theodoro de Bry, 1596; DE BRY, T. Americae Pars VII. Verissima et ivcvndissima descriptio praecipvarvm qvarvndam Indiae regionum \& insularum, quae quidem nullis ante haec tempora visae cognitaeque, iam primum ab Vlrico Fabro Straubingensi, multo cum periculo inuentae \& ab eodem summa diligentia consignate suerunt, ex germanico in latinum sermonem conuersa autore M. Gotardo Artvs Dantiscano. Francofurte: Theodorici de Bry viduae \& filiorum, 1599; DE BRY, T. Americae Pars VIII. Continens Primo, descriptionem trivm itinervm nobilissimi et fortissimi Eqvitis Francisci Draken, qvi peregrato primvm Universo Terrarvm Orbe, postea cum nobilissimo Eqvite Iohanne Havckens, ad expugnandum ciuitatem Panama, in Indiam nauigauit, vbi vitam suam ambo finierunt. Francofurte: Theodorici de Bry Viduae $\&$ filiorum, 1599; DE BRY, T. Americae Nona \& postrema Pars. Qva de ratione elementorvm: de Novi Orbis natvra: de hvivs incolarvm svperstitiosis cultibus: deq; forma Politiae ac Reipubl. ipsorum copiosè pertractatur. Francoforti ad Moenum: Matth[aus] Beckervm, 1602. 
sem dúvida alguma constitua uma referência fundamental para a iconografia seiscentista ${ }^{11}$, a análise preliminar dos antigos mapas depositados na Coleção de Arte ABN AMRO REAL (São Paulo) terminaria por levantar indagações quanto a essa assertiva, circunstância que tornou pertinente a realização de um estudo mais detalhado sobre a "America" de Jodocus Hondius ali depositada (número de tombo 0767), no caso um exemplar oriundo da edição francesa de $1619^{12}$.

\section{Os elementos iconográficos}

Impressa a partir de uma chapa de cobre com $500 \mathrm{~mm}$ de comprimento e $375 \mathrm{~mm}$ de altura, a "America" de Hondius mostra um continente de limites indefinidos onde o extremo se confunde com a Ásia, enquanto a Terra do Fogo constitui mera projeção de uma vasta "Terra Australis" apenas imaginada ${ }^{13}$. Como ornamento, esse mapa apresenta 17 ilustrações sempre localizadas à margem das massas continentais, cabendo à área do Oceano Atlântico um total de sete imagens $(41,18 \%)$, três das quais situadas no Atlântico Norte (17,65\%) e quatro no Atlântico Sul (23,53\%). As dez ilustrações restantes (58,82\%) se distribuem pela amplidão do Oceano Pacífico, estando divididas igualmente em dois grupos de cinco $(29,41 \%)$ entre o Pacífico Sul e Norte.

Das 17 gravuras presentes, apenas cinco (29,41\%) estão acompanhadas de observações em latim, havendo dois exemplos $(11,76 \%)$ de imagens seguidas de comentários escritos em cartuchos adjacentes, bem como um caso isolado $(5,88 \%)$ no qual figura e texto terminaram inclusos no mesmo cartucho de grande porte. Nada menos de 15 composições $(88,24 \%)$ encontram-se restritas a um único elemento figurativo, enquanto duas (11,76\%) agregam entre dois e mais de uma dúzia de motivos distintos (Fig. 1). Em termos de seu maior comprimento,

11 Vide DUCHET, M. (Org.). L' Amérique de Théodore de Bry: une collection de voyages protestante du XVIe siècle, quatre études d' iconographie. Paris: Editions du Centre National de la Recherche Scientifique, 1987.

12 Segundo os detalhes fornecidos por KOEMAN, C. Atlantes Neerlandici: bibliography of terrestrial, maritime and celestial atlases and pilot books published in the Netherlands up to 1880. Amsterdam: Theatrum Orbis Terrarum, 1967.

13 Vide KRETSCHMER, K. Historia de la geografía. Barcelona: Editorial Labor, 1942. 
uma dessas estampas revela-se assaz discrepante por alcançar $224 \mathrm{~mm}$ enquanto todas as outras oscilam entre $62 \mathrm{~mm}$ e apenas $11 \mathrm{~mm}$ (vide adiante).

Grosso modo, as 17 ilustrações observadas na "America" de Hondius podem ser divididas em três grupos principais referentes a animais marinhos ou monstros fabulosos (sete gravuras - 41,18\%), navios europeus (cinco gravuras - 29,41\%) e um tipo peculiar de "cenas de costumes" quase sempre associado a embarcações indígenas (cinco gravuras - 29,41\%). No entanto, esse último elenco também inclui uma composição assaz destoante pelo tamanho, fatura elaborada e sobretudo por representar índios brasileiros, sendo a única imagem da "America" dedicada a um tema não relacionado ao universo dos oceanos e navegações de qualquer espécie. Na verdade, a inserção de barcos europeus e animais marinhos - reais ou imaginários - nessa carta geográfica não causa maior surpresa, pois motivos desse tipo podem ser observados em numerosos trabalhos dos séculos XVI e XVII, estando presentes até mesmo em mapas bem mais despojados como o primoroso "Dell' Arcano del Mare" ${ }^{14}$. Embora compreendam 12 gravuras e representem a ampla maioria das ilustrações existentes (70,58\%), as duas primeiras categorias assumem posição absolutamente secundária face às "cenas de costumes", tendência bem marcada tanto pelo porte e qualidade das imagens quanto pelo fato de só estas últimas contarem com textos anexos. Semelhante complexidade torna necessária a análise individual de tais estampas, enquanto as restantes podem ser examinadas em conjunto sem maior prejuízo.

\section{As "cenas de costumes"}

\subsection{Caiaque esquimó}

Situada entre a Irlanda, a Islândia e a Península do Labrador, essa gravura de 46×22 $\mathrm{mm}$ mostra um homem com feições européias e um pesado traje de inverno navegando em um caiaque esquimó (Fig. 2). Sua mão direita empunha o típico remo duplo em posição de descanso, enquanto a esquerda se prepara - com o auxílio de um propulsor - para lançar um

14 DUDLEY, R. Dell' arcano del mare. Firenze: Stamperia di Francesco Onofri, 1646-1647. 
tridente contra uma ave muito estilizada, a qual parece agitar a superfície d'água em sua tentativa de fuga. Abaixo da ilustração, uma sentença latina esclarece que os

habitantes da Groenlândia utilizam certo tipo de embarcação feita de couro na qual um único homem cruza o mar com o auxílio de um só remo. Na mão direita tem um instrumento com o qual as aves astutas são lanceadas ("Groenlandi utuntur certo navigij genere ex corijs facto, in quo locus salummodo unius hominis, cui tant .i. remo opus est. Dextra instrumentum tenent quo astute aves jaculantur").

A presença de um caiaque em um mapa impresso no princípio do século XVII chama a atenção pela própria história dos antigos testemunhos iconográficos sobre os esquimós. Com efeito, a primeira representação conhecida desses habitantes das terras setentrionais parece resumir-se a uma tosca gravura publicada pelo arcebispo sueco Olaus Magnus em sua raríssima “Carta Marina" de $1539^{15}$, imagem repetida algumas décadas mais tarde na célebre "Historia de Gentibus Septentrionalibus" de Olaus Magnus ${ }^{16}$. Embora canoas de silhueta alongada também estejam presentes, em nenhum caso foi possível obter a identificação positiva de um caiaque.

No último quartel do século XVI, os esquimós voltariam a ser retratados graças às atividades de Martin Frobischer, famoso corsário inglês bem conhecido dos interessados nas viagens de exploração ${ }^{17}$. Engajado na disputa travada

15 Vide reproduções em BJøRNBO, A. A. Cartographia Groenlandica. Dansk Polarcenter: København, 1912; LYNAM, E. The Carta Marina of Olaus Magnus, Venice 1539 and Rome 1572. Jenkintown: Tall Tree Library, 1949.

16 OLAUS MAGNUS. Historia de gentibvs septentrionalibvs. Romae: Joannes Maria de Viottis, 1555.

17 Mais informações em COLLINSON, R. (Ed.). The three voyages of Martin Frobisher in search of a passage to Cathaia and India by the north-west, A.D. 1576-8. London: Hakluyt Society, 1867; CROUSE, N. The search of Northwest Passage. New York: Columbia University Press, 1934; FROBISHER, K. A. Elizabethan hero: the life of Sir Martin Frobisher. North Charleston: BookSurge Publishing, 2006; HOWGEGO, R. J. Encyclopedia of exploration to 1800. Potts Point: Hordern House, 2003; McDERMOTT, J. Martin Frobisher: Elizabethan privateer. New Haven: Yale University Press, 2001; McFEE, W. The life of Sir Martin Frobisher. New York: Harper and Brothers, 1928; McGHEE, R. The artic voyages of Martin Frobisher: an Elizabethan adventure. Seattle: University of Washington Press, 2001; TAYLOR, E. G. R. Tudor geography, 1485-1583. London: Methuen \& Co., 1930. 
entre a Inglaterra Elisabetana e os Impérios Ibéricos pelas cobiçadas riquezas do ultramar, Frobisher seria o primeiro navegante - desde Sebastian Cabot - a partir em busca de uma "passagem do noroeste" que constituísse uma rota alternativa para os tesouros das "Índias" e da China, tendo realizado três expedições à Terra de Baffin (1576, 1577 e 1578), onde percorreu os arredores da baía posteriormente nomeada em sua homenagem.

De acordo com os testemunhos disponíveis, os primeiros contatos com os esquimós ocorreram em 19 de agosto de 1576, já perto do final da estada na região. Bastante amistosas no princípio, essas relações terminariam por deteriorar-se com rapidez devido ao seqüestro de cinco homens do "Gabriel" - o único navio remanescente - pelos nativos locais e à conseqüente retaliação dos ingleses, os quais capturaram um esquimó adulto na tentativa de obter reféns capazes de trazer de volta os tripulantes perdidos. Como as negociações se monstraram impossíveis, Frobischer retornaria para casa levando esse cativo e todos os seus apetrechos, tendo chegado a Londres no dia 9 de outubro de 1576. Motivo de grande espanto nos mais variados círculos, o esquimó prisioneiro despertou o interesse de Lucas de Heere, pintor flamengo exilado nessa capital, que retratou esse "Homme sauvage... des pais Septentrionaux par M. Furbisher L'an 1576" no "Theatre de tous les peuples et nations de la terre", extenso manuscrito ilustrado redescoberto apenas há poucas décadas ${ }^{18}$.

Ao partir para a segunda viagem no ano seguinte, Frobisher acalentava o plano de capturar mais esquimós para concluir o resgate dos cinco tripulantes aprisionados na incursão anterior. Após diversas peripécias, a expedição voltaria a Bristol trazendo um casal de esquimós com uma criança de colo, acontecimento destinado a atrair a atenção da própria Rainha Elizabeth I. Não obstante, todos estavam destinados a sucumbir em um prazo bastante curto, pois o homem morreu de pneumonia em dois meses e a mulher tampouco durou muito. Haveria tempo suficiente, porém, para esses infelizes protagonizarem verdadeiros espetáculos, sendo digno de nota o registro de o homem ter percorrido de caiaque o porto de Bristol, quando impressionou a todos pela notável habilidade demonstrada em abater patos em pleno vôo com dardos es-

18 Vide BIRKET-SMITH, K. The earliest Eskimo portraits. Folk, n. 1, p. 6-14, 1959; OSWALT, W. H. Eskimos and explorers. Novato: Chandler \& Sharp Publishers, 1979. 
peciais lançados com o auxílio de um propulsor ${ }^{19}$. Em linhas gerais, esta parece ser exatamente a cena representada na "America" de Jodocus Hondius, tanto mais que certos dardos empregados pelos esquimós nesse tipo de caçada - os chamados "nuiq" - se assemelham a estranhos tridentes ${ }^{20}$ (Fig. 2).

Constituindo um bom exemplo dos iletrados homens de ação do século XVI, Frobisher jamais se preocupou em narrar suas incursões ao extremo norte e muito menos representou os habitantes locais. Na verdade, semelhante tarefa caberia a outros participantes dessas viagens ${ }^{21}$, os quais escreveram relatos de extensão variável às vezes divulgados por intermédio de terceiros ${ }^{22}$. Em termos dos registros iconográficos produzidos, o renomado artista inglês John White merece destaque como provável autor de algumas das mais antigas - e sem dúvida as mais fidedignas - imagens de esquimós referentes a esse período, pinturas usualmente atribuídas aos nativos observados e/ou capturados durante a expedição de $1577^{23}$.

Para efeito da presente análise, a segunda tentativa de Frobisher ganha importância tanto pela presença de John White quanto pelo testemunho conferido por Dionyse Settle, gentil-homem que acompanhou a viagem de 1577 na qualidade de representante do Conde de Cumberland, um dos interessados

19 BIRKET-SMITH, K. The earliest Eskimo portraits. Folk, n. 1, p. 6-14, 1959; CHESHIRE, N.; WALDRON, T.; QUINN, A.; QUINN, D. Frobisher's Eskimos in England. Archivaria, n. 10, p. 23-50, 1980; LEE, S. The American Indian in Elizabethan England. In: BOAS, F. S. (Ed.). Elizabethan and other essays. Oxford: Clarendon Press, 1929. p. 263-301; OSWALT, W. H. Eskimos and explorers. Novato: Chandler \&t Sharp Publishers, 1979.

20 Vide CRANTZ, D. The History of Greenland. London: Brethren's Society, 1767.

21 Por exemplo BEST, G. A true discourse of the late voyages of discouerie, for the finding of a passage to Cathaya, by the Northweast, vnder the conduct of Martin Frobisher Generall. London: Henry Bynnyman, 1578; ELLIS, T. A True Reporte of the Third and Last voyage into Meta Incognita: atchieved by the worthie Capteine, M. Martine Frobisher, esquire, Anno. 1578. London: Thos. Dawson, 1578.

22 Por exemplo em HAKLUYT, R. The Principall Nauigations, Voiages, Traffiqves and Discoueries of the English Nation, made by Sea or ouer-land, to the remote, and farthest distant quarters of the Earth, on any time within the compasse of these 1500 yeeres. London: George Bishop, Ralph Newberie and Robert Barker, 1598-1600.

23 BIRKET-SMITH, K. op.cit.; CHESHIRE, N.; WALDRON, T.; QUINN, A.; QUINN, D. op.cit. p. 23-50, 1980; HULTON, P. H. John White's Drawings of Eskimos. The Beaver, n. 41 (1), p. 16-20, 1961; OSWALT, W. H. op.cit. 
na empreitada. Ainda nesse mesmo ano, Settle traria à luz uma narrativa sobre a expedição sob o título de "A true reporte of the laste voyage into the West and Northwest regions... atchieved by Capteine Frobisher", livro destinado a alcançar enorme sucesso na época ${ }^{24}$. A entusiástica acolhida dispensada conduziu ao lançamento subseqüente da mesma obra em francês e em latim ${ }^{25}$, traduções enriquecidas por pranchas calcadas em pretensos originais de John White hoje desaparecidos $^{26}$. Tais ilustrações, por seu turno, terminariam sendo relacionadas a Theodore de Bry, pois o mestre flamengo de fato travou relações com White durante sua primeira visita à Inglaterra, tendo reproduzido vários trabalhos do pintor elisabetano (vide adiante). No entanto, o encontro em questão ocorreu cerca de oito anos após a publicação da "Navigation du capitaine Martin Forbisher"27, isso sem contarmos que as poucas pinturas de esquimós atribuídas a John White são de natureza muito distinta e permaneceram esquecidas por longo tempo, jamais tendo sido aproveitadas como fonte para a confecção de qualquer tipo de gravura ${ }^{28}$.

Entre outras peculiaridades, as versões francesa e latina do volume de Dionyse Settle incluem a vista de uma costa rochosa onde esquimós com feições européias são retratados junto a objetos e tarefas do cotidiano, notando-se um trenó com seu cachorro, mulheres de longos cabelos levando crianças nas costas e homens carregando caiaques - na verdade uma das primeiras representações conhecidas de semelhante embarcação. Em primeiro plano, um caçador navega em outro desses

24 SETTLE, D. A true reporte of the laste voyage into the West and Northwest regions, Etc. 1577. worthily atchieved by Capteine Frobisher of the sayde voyage the first finder and Generall. London: Henrie Middleton, 1577.

25 Idem, La navigation du capitaine Martin Forbisher Anglois ès regions de west Et Nordwest, en l'année MDLXXVII. Geneva: Anthoine Chuppin, 1578;

De Martini Forbisseri Angli nauigatione in regiones occidentis et septentrionis narratio historica, ex Gallico sermone. Noribergae: In officina Catharinae Gerlachin \&t Haredum Johanis Montani, 1580.

26 OSWALT, W. H. Eskimos and explorers. Novato: Chandler \& Sharp Publishers, 1979.

27 SETTLE, D. De Martini Forbisseri Angli nauigatione in regiones occidentis et septentrionis narratio historica, ex Gallico sermone. Noribergae: In officina Catharinae Gerlachin \& Haredum Johanis Montani, 1580.

28 BIRKET-SMITH, K. The earliest Eskimo portraits. Folk, n. 1, p. 6-14, 1959; OSWALT, W. H. op.cit. 
frágeis barcos de couro sustentando o remo duplo com a mão esquerda, enquanto a direita se prepara - com o auxílio de um propulsor - para lançar um curioso tridente contra um pato pousado na superfície d'água, ao passo que um segundo exemplar voa com dificuldade por já ter um desses dardos cravados no corpo. Quase um século depois, essa mesma imagem ainda estaria presente em coletâneas de certos autores seiscentistas como Arnoldus Montanus ${ }^{29}$ (Fig. 2).

Alguns detalhes, entretanto, parecem estar ausentes do livro de Dionyse Settle, sendo particularmente curioso o confesso desconhecimento desse autor sobre o emprego dos "nuiq", tipo de arma em grande evidência na prancha em questão. Tampouco as feições nitidamente europeizadas dos esquimós representados e os elementos arbóreos observados ao fundo fazem justiça a um artista tão preciso como John White, pois a Terra de Baffin se encontra no domínio da tundra ${ }^{30}$, possuindo uma paisagem inóspita descrita pelo próprio Settle como de nuas montanhas escarpadas cobertas por grande quantidade de neve, muito pouca relva e nenhuma vegetação de maior porte ${ }^{31}$. Contrariando determinadas opiniões ${ }^{32}$, essa composição talvez deva ser entendida como uma espécie de alegoria baseada tanto em textos ${ }^{33}$ quanto na experiência proporcionada pelos pobres

29 MONTANUS, A. De Nieuwe en Onbekende Weereld: of Beschryving van America en't Zuid-Land, Vervaetende d'Oorsprong der Americaenen en Zuidlanders, gederkwaerdige togten derwaerds, Gelegendheit Der vaste Kunsten, Eilanden, Steden, Sterkten, Dorpen, Tempels, Bergen, Fonteinen, Stroomen, Huisen, der natuur van Beesten, Boomen, Planten en vreemde Gewasschen, Gods-dienst en Zeden, Wonderlijke Voorvallen, Vereeuwde en Nieuwe Oorloogen. Amsterdam: Jacob van Meurs, 1671.

30 Vide BARBOUR, M. G.; BILLINGS, W. D. (Ed.). North American terrestrial vegetation. Cambridge: Cambridge University Press, 1988; PORTER, R. W. Frobisher Bay Revisited. Journal of the American Society of New York 30 (2): 97-110, 1898.

31 SETTLE, D. A true reporte of the laste voyage into the West and Northwest regions, Etc. 1577. worthily atchieved by Capteine Frobisher of the sayde voyage the first finder and Generall. London: Henrie Middleton, 1577.

32 Por exemplo OSWALT, W. H. Eskimos and explorers. Novato: Chandler \&t Sharp Publishers, 1979.

33 Por exemplo SETTLE, D. op.cit.; BEST, G. A true discourse of the late voyages of discouerie, for the finding of a passage to Cathaya, by the Northweast, vnder the conduct of Martin Frobisher Generall. London: Henry Bynnyman, 1578. 
esquimós levados para a Inglaterra no ano de 1577. Nesse sentido, não só vale lembrar a já mencionada caçada de patos levada a cabo no porto de Bristol, mas também recordar que, na versão latina do texto de Settle, essa gravura se encontra legendada como a "pintura ou desenho dos homens recentemente trazidos da Inglaterra, junto com suas armas, tendas e canoas" ("Pictura vel Delineatio Hominum Nuper ex Anglia Advectorum, una cum eorum armis, tentoriis \& naviculis") (Fig. 2).

Mesmo um breve exame basta para demonstrar a óbvia relação existente entre a prancha do livro de Dionyse Settle e o detalhe da "America", embora esse último limite-se a reproduzir a efígie do caçador esquimó em seu caiaque (Fig. 2). Além de parcial e algo estilizada, a cópia de Jodocus Hondius surge como a imagem especular do modelo utilizado - provável efeito da técnica empregada na execução desse mapa (vide adiante). No entanto, a legenda de Hondius não contempla semelhante particularidade e descreve brevemente a disposição encontrada na estampa original, lapso que explicaria as incongruências observadas entre o desenho e a sentença anexa. 0 inegável sucesso e a aparente raridade da edição inglesa do relato de Settle tornam razoável a hipótese de Jodocus Hondius ter tomado conhecimento dessa narrativa através das versões francesa ou latina, tampouco cabendo descartar a influência de eventuais comentários sobre os exóticos "homens do norte" levados para a Inglaterra anos antes de sua chegada a Londres.

\subsection{Canoa algonquina}

Disposta ao largo da costa leste da América do Norte, essa segunda gravura de 56×13 mm mostra uma piroga tripulada por dois homens nus com feições indistintas que impulsionam a embarcação com remos de longos cabos. No centro, dois vultos sentados parecem aquecer-se em torno de uma pequena fogueira acesa desprendendo rolos de fumaça, enquanto no costado da proa repousa uma rede de pesca (Fig. 3). Logo abaixo, uma frase latina estabelece ser esta uma "canoa dos nativos da Flórida, escavada com fogo a partir de um tronco de uma única árvore" ("Navicula Floridanum ex trunco unius arboris, ignis exusta”).

De forma bastante estilizada, essa pequena ilustração reproduz uma das inconfundíveis aquarelas de indígenas norteamericanos elaboradas por John White (vide acima), famoso artista elisabetano que acompanhou parte das chamadas "Roanoke Voyages" (1584-1590) à costa leste da América do Norte. Promovidas por Sir Walter Raleigh, tais viagens representam 
a primeira tentativa concreta de estabelecimento dos ingleses nessa parte do continente, episódio bem conhecido sobre o qual existe copiosa bibliografia ${ }^{34}$.

Após uma exploração preliminar efetuada em 1584, os comandados de Raleigh escolheram a Ilha de Roanoke, litoral da Carolina do Norte, como o sítio adequado para o futuro assentamento, o qual foi criado em meados de 1585 sob o comando de Sir Richard Grenville. Congregando cerca de uma centena de almas em torno de um recinto fortificado e algumas casas, a recém-fundada colônia terminou sendo abandonada em 18 de junho de 1586.

Em 8 de maio de 1587, três barcos partiriam de Plymouth levando pouco mais de 100 colonos para Roanoke, contingente liderado pelo próprio John White. Após um mês de permanência, as enormes dificuldades enfrentadas pelos novos habitantes obrigaram White a voltar para a Inglaterra em busca de recursos adicionais. Sujeito a incontornáveis obstáculos, o esperado socorro só chegaria em agosto de 1590 - três anos mais tarde - encontrando apenas ruínas de edifícios abandonados e um poste de madeira onde alguém escavara o nome de uma ilha vizinha ("Croatoam"), enigmática inscrição cujo sentido ainda permanece tão obscuro quanto o destino dos desaparecidos moradores do vilarejo.

$\mathrm{Na}$ qualidade de cartógrafo e desenhista engajado na expedição de 1585-1586, John White produziu mais de setenta aquarelas e desenhos voltados para a fauna, flora e os habitantes do Novo Mundo, obra destinada a garantir-lhe a fama

34 Maiores informações em BROWN, A. The genesis of United States. Boston: Houghton Mifflin, 1890; EDWARDS, E. The life of Sir Walter Ralegh. London: Macmillan, 1868; FULLER, M.C. Voyages in print: English travel to America, 1576-1624. Cambridge: Cambridge University Press, 1995; HAKLUYT, R. The Principall Nauigations, Voiages, Traffiqves and Discoueries of the English Nation, made by Sea or ouer-land, to the remote, and farthest distant quarters of the Earth, on any time within the compasse of these 1500 yeeres. London: George Bishop, Ralph Newberie and Robert Barker, 1598-1600; HOWGEG0, R. J. Encyclopedia of exploration to 1800. Potts Point: Hordern House, 2003; MORISON, S.E. The European discovery of America: the Northern Voyages A.D. 500 - 1600. New York: Oxford University Press, 1971; PURCHAS, S. Pvrchas his Pilgrimage. Or Relations of the World and the Religions Obserued in all Ages and places Discouered, from the Creation vnto this Present. Contayning a Theologicall and Geographicall Historie of Asia, Africa, and America, with the Islands adiacens. London: Willian Stansby, 1626; QUINN, D. B. (Ed.). The Roanoke voyages 1585-1590: documents to illustrate the English voyages to North America under the patent granted to Walter Raleigh in 1584. London: Hakluyt Society, 1955. 
de autor da primeira iconografia relevante sobre o continente americano, assertiva quiçá um tanto exagerada ${ }^{35}$. Sem embargo, os trabalhos de White indubitavelmente constituem uma fonte inigualável para o estudo dos antigos secotans, nação algonquina que habitou a costa da Carolina do Norte até ser devastada pelos europeus durante o século XVII ${ }^{36}$.

No curso da segunda investida a Roanoke, John White trabalharia em estreita colaboração com Thomas Harriot, astrônomo e matemático encarregado de prestar auxílio à navegação, mapear os novos domínios, observar os indígenas locais e listar os recursos naturais da região. Essas minuciosas anotações vieram à luz em "A briefe and true report of the new found land of Virginia”, obra publicada em 1588 sob a forma de um pequeno volume "in-quarto" bastante raro nos dias de hoje $\mathrm{e}^{37}$. Dois anos mais tarde, a narrativa em foco seria objeto de uma nova edição mais cuidada e acrescida de várias gravuras de Theodore de Bry baseadas em originais de John White $^{38}$. Sob o título de "Admiranda Narratio fida tamen, de

35 Vide CROFT-MURRAY, E.; HULTON, P. Catalogue of British drawings.

London: British Museum, 1960. v. I: XVI \& XVII Centuries; P.H. Hulton in HARRIOT, T. A briefe and true report of the New Found Land of Virginia. New York: Dover, 1972; HULTON, P. H. American 1585: the complete drawings of John White. Chapel Hill: University of North Carolina Press, 1984; HULTON, P. H.; QUINN, D. B. The American drawings of John White, 15771590. London \&t Chapel Hill: Trustees of the British Museum \& University of North Carolina Press, 1964; HULTON, P. H.; QUINN, D. B. The American drawings of John White 1577-1590 with Drawings of European and Oriental Subjects. Burlington Magazine, n. 107 (751), p. 527-528, 1965; LORANT, S. (Ed.). The New World: the first pictures of America. New York: Duell, Sloan \& Pearce, 1946; WALLIS, H. M. Raleigh and Roanoke, the First English colony in America: the British Library exhibit hosted by the North Carolina Museum of History. Raleigh: America's Four Hundredth Anniversary Committee \&t North Carolina Department of Cultural Resources, 1985.

36 FEEST, C. F. North Carolina Algonquians. In: TRIGGER, B. (Ed.). Handbook of North American Indians. Washington, DC: Smithsonian Institution. 1978. p.271-281. v. 15, Northeast; HOFFMAN, B. G. A summary of Indian distribution and movements in Northeastern United States from 1534 to 1779. Parts I-III. Ethnohistory, n. 14 (1/2), p. 1-46, 1967.

37 HARRIOT, T. A briefe and true report of the new found land of Virginia: of the commodities there found and to be raysed, as well merchantable, as others for victuall, building and other necessarie vses for those that are and shal be the planters there. London: [s.n], 1588.

38 HARRIOT, T. A briefe and true report of the new found Land of Virginia, of the commodities and of the nature and manners of the naturall inhabitants. Frankfurt am Main: Theodor de Bry, 1590. 
commodis et incolarum ritibus Virginiae...", De Bry lançaria uma versão em latim logo em seguida como o primeiro volume de suas "Grand Voyages" 39 . Revelando-se um "livro de viagens" de méritos inegáveis, o relato de Harriot alcançaria um sucesso inaudito já em sua época, constituindo uma das principais referências disponíveis sobre a América do Norte ao longo de quase um século ${ }^{40}$.

Entre as pinturas de John White reproduzidas por Theodore de Bry, uma das mais notáveis retrata as diferentes modalidades de pesca praticadas pelos secotans, ilustração correspondente à prancha XIII em ambas as edições - latina e inglesa - publicadas no ano de 1590. Intitulada nesta última como "Sua maneira de pescar na Virgínia" ("Their manner of fishynge in Virginia”), a composição de Theodore de Bry omite certos detalhes e acrescenta outros inexistentes no original, mas reproduz com fidelidade os nativos pescando - em canoas ou dentro d'água - com o auxílio de arpões, redes e armadilhas diversas, além de figurar alguns elementos da fauna e flora - inclusive a primeira representação conhecida de um caranguejo-ferradura, Limulus polyphemus (Linnaeus, 1758) ${ }^{41}$ (Fig. 3).

A exemplo do caso anterior, Jodocus Hondius terminaria por desprezar os elementos secundários da prancha de Theodore de Bry, lançando mão do motivo principal - a canoa tripulada por quatro indígenas - para construir uma imagem especular bastante simplificada do modelo escolhido (Fig. 3). No entanto, a breve legenda que acompanha esse detalhe da "America" não guarda qualquer relação com os extensos comentários sobre as pescarias dos nativos encontrados no texto original. Na verdade, a observação de Hondius sobre essa canoa ter sido "escavada com fogo em um único tronco de árvore” parece estar relacionada ao texto da prancha XII, em

39 DE BRY, T. Admiranda Narratio fida tamen, de commodis et incolarvm ritibvs Virginiae, nvper admodvm ab anglis, qvi à Dn. Richardo Greinville eqvestris ordines viro è in colonian Anno M.D.LXXXV dedvcti sunt inventae, svmtvs faciente Dn. Waltero Raleigh eqvestris ordinis viro fodinarv stanii praefecto ex avctoritate Serenissima Reginae Angliae. Francoforti ad Moenvm: Typis Ioannis Wecheli, 1590.

40 CAMPBELL, M. B. The witness and the other world: exotic European Travel Writing 400-1600. Ithaca: Cornell University Press, 1988; FULLER, M.C. Voyages in print: English travel to America, 1576-1624. Cambridge: Cambridge University Press, 1995.

41 CALMAN, W. T. An early figure of the King-crab, Limulus polyphemus. Science, n. 27, April 1908. p. 669. 
que Harriot descreve como os secotans faziam seus botes ("The manner of makinge their boates", vide Fig. 3). Nas palavras do naturalista inglês, essas embarcações eram construídas em troncos inteiros de árvores, sendo moldadas graças ao proverbial recurso de queimar a madeira e raspar as partes carbonizadas com o auxílio de conchas ${ }^{42}$.

\subsection{Canoa alakaluf}

Ocupando o extremo sul da Patagônia, essa terceira gravura alcança $62 \times 22 \mathrm{~mm}$ e retrata uma canoa de proa dupla com formato bastante recurvado e afilado. No centro dessa curiosa embarcação, uma fogueira crepitante desprende rolos de fumaça e aquece um estranho casal de feições européias. Ambos permanecem sentados trajando apenas um manto jogado às costas, sendo que a mulher parece amamentar uma criança de colo enquanto o homem movimenta a piroga com auxílio de um remo de cabo longo (Fig. 4). Logo abaixo, um cartucho decorado contém a sentença "embarcação de couro usada pelos habitantes do Estreito de Magalhães, onde o fogo queima sem cessar" escrita em latim ("Navigium ex corijs co accolae Freti Magellanici utuntur, in quo continue ign struunt").

Compondo uma cena bastante característica, a presente ilustração sem dúvida alguma retrata os chamados "índios canoeiros" da Terra do Fogo, termo geral aplicado aos chonos do Golfo de las Peñas, aos yahgans do Canal de Beagle e sobretudo aos alakaluf do Estreito de Magalhães, os quais teriam sido os primeiros descobertos pelos navegadores europeus. Apesar de os misteriosos fogos avistados, em 1520, por Fernão de Magalhães serem amiúde atribuídos aos alakaluf, o contato efetivo com esses nativos ocorreria seis anos mais tarde durante a expedição realizada por Frei Garcia Jofre de Loayasa ${ }^{43}$.

42 HARRIOT, T. A briefe and true report of the new found Land of Virginia, of the commodities and of the nature and manners of the naturall inhabitants. Frankfurt am Main: Theodor de Bry, 1590.

43 Frei Loayasa in OVIED0 y VALDEZ, G.F. De la segunda parte de la general historia delas Indias. Valladolid: Francisco Fernandez de Cordoua, 1557. Vide também MARKHAM, C. Early Spanish voyages to the Strait of Magellan. London: Hakluyt Society, 1911; PIGAFETTA, A. Relation du premier voyage autour du monde par Magellan 1519-1522. Anvers \& Paris: Editions Gust Janssens \& Editions Ernest Leroux, 1923. 
Ao todo, haveria apenas nove publicações dignas de nota sobre os alakaluf em todo o século XVI e sete outras no século XVII, elenco que inclui vários testemunhos de fontes inglesas e holandesas ${ }^{44}$.

Tal como no caso dos ingleses (vide acima), as ousadas viagens holandesas do século XVI refletem a inexorável ascensão da burguesia dos Países Baixos, processo determinante para a derrocada final dos gigantescos e decadentes impérios ultramarinos de Portugal e Espanha. Tendo o comércio do Báltico sob seu controle e intermediando quase todas as transações entre as metrópoles coloniais e o resto da Europa, os holandeses acirrariam a feroz disputa pelas riquezas do alémmar ao se insurgirem contra a Espanha em 1572, revolução que transformou as Províncias Unidas na maior potência naval do século XVII. Pondo de lado suas rivalidades internas, os diversos interesses mercantes terminariam por se unir em torno de Companhias destinadas a constituir verdadeiros departamentos do nascente Estado flamengo, estratégia bem marcada pela fundação, respectivamente em 1602 e 1621, das famosas Companhias Privilegiadas das Índias Orientais e 0cidentais ${ }^{45}$.

Tal consenso, entretanto, ainda não havia sido alcançado no final do século XVI, quando grupos isolados buscavam diferentes alternativas para alcançar os tesouros das “Índias". Em 1598, Pieter van den Hagen e Johan van der Veken, dois ricos varejistas de Rotterdam, financiariam uma expedição de cinco navios e cerca de 500 homens que pretendia chegar às Molucas - grande centro produtor de especiarias - passando através do Estreito de Magalhães, rota tradicional dos navegadores espanhóis ${ }^{46}$. Sob a liderança do Almirante Jacques Mahu, os embarcados deixaram Goeree em

44 J. Bird in STEWARD, J. H. (Ed.). Handbook of South American Indians. v.1: The Marginal Tribes. Bureau of American Ethnology Bulletin, n. 143, p. 1624, 1946; COOPER, J. M. Analitycal and critical bibliography of the tribes of Tierra del Fuego and adjacent territory. Bureau of American Ethnology Bulletin, Washington, n. 63, p. 1-233, 1917.

45 BOXER, C. R. The Dutch Seaborne Empire 1600-1800. London: Hutchinson, 1965; ISRAEL, J. I. The Dutch Republic: its rise, greatness, and fall 14771806. Oxford: Oxford University Press, 1995; DE VRIES, J. \& WOUDE, A. van der. The first modern economy: sucess, failure and perseverance of the Dutch economy, 1500-1815. Cambridge: Cambridge University Press, 1997.

46 BEAGLEHOLE, J. C. The exploration of the Pacific. London: Adam \& Charles Black, 1947; MARKHAM, C. Early Spanish voyages to the Strait of Magellan. London: Hakluyt Society, 1911. 
27 de junho de 1598, dando início a uma das mais aziagas viagens holandesas de todos os tempos ${ }^{47}$.

Retida pelos ventos contrários na costa da Inglaterra, a frota só atingiu as ilhas do Cabo Verde no final de agosto, permanecendo no arquipélago até o final de setembro. Como alguns tripulantes - entre os quais o próprio Jacques Mahu - morreriam de febre nesse ínterim, a equipagem passou a responder ao Vice-Almirante Simon de Cordes, tendo Gerrit van Beuningen como o segundo em comando. Este último ocuparia o lugar do finado Jacques Mahu à frente da capitânia, tendo sido substituído na ponte de sua antiga embarcação - um vaso de 320 toneladas chamado "Geloof" ("Fé") e guarnecido por 105 homens - por Sebald de Weert, um dos melhores e mais experimentados marinheiros holandeses da época.

Vitimados pelo escorbuto, os viajantes seriam forçados a buscar provisões na ilha de Ano Bom e na costa africana adjacente, iniciando a travessia do Atlântico em 3 de janeiro de 1599. Após ultrapassar o Arquipélago de Abrolhos em 22 de janeiro, os navios atingiram o Rio da Prata em 12 de março, aventurando-se pelo Estreito de Magalhães em 6 de abril. Imobilizada por fortes ventos contrários em 18 de abril, a expedição foi obrigada a invernar em uma baía até 23 de agosto, perdendo mais de 100 homens devido ao clima adverso e à ação de indígenas hostis. Em 3 de setembro de 1599, o Oceano Pacífico

47 Maiores informações em DE BOER, M. G. Van Oude voyagiën. Amsterdam: Meulenhoff, 1912-1913; DE BROSSES, C. Histoire de Navigations aux Terres Australes. Paris: Durand, 1756; BRUIJN, J. R.; GAASTRA, F. S.; SCHÖFFER, I. (Ed.). Dutch-Asiatic shipping in the 17th and 18th centuries. The Hague: Martinus Nijhoff, 1979-1987; VAN DAM, P. Beschryvinge van de Oostindische Compagnie. Gravenhage: Martinus Nijhoff, 1927; FLOORE, P.; GAWRONSKI, J. H. G. Nederlanders in de straat van Magalhães: zoektocht naar sporen van de overwintering van de vloot van Mahu en De Cordes in 1599. Amsterdam: Stichting Olivier van Noort \& Universiteit van Amsterdam, 1999; HARRIS, J. Navigantium atque Itinerantium Bibliotheca. London: T. Osborne, 1764; HOWGEG0, R. J. Encyclopedia of exploration to 1800. Potts Point: Hordern House, 2003; KERR, R. (Org.). A general history and collection of voyages and travels, arranged in systematic order forming a complete history of the origin and progress of navigation, discovery and commerce, by sea and land, from the earliest ages to the present time. Edinburgh \& London: W. Blackwood \& T. Cadell, 1824; KOEMAN, C. Atlantes Neerlandici: bibliography of terrestrial, maritime and celestial atlases and pilot books published in the Netherlands up to 1880. Amsterdam: Theatrum Orbis Terrarum, 1967; MEILINK-

ROELOFSZ, M. A. P. De V.O.C. in Azië. Bussum: Fibula-van Dishoeck, 1976; MOLLEMA, J. C. De Nederlandsche vlag op de wereldzeeёn Ontdekkingsreizen onzer voorouders. Amsterdam: Scheltens \& Giltay, [ca. 1940]; WIEDER, F. C. De Reis van Mahu en De Cordes door de Straat van Magalhaes naar ZuidAmerica en Japan, 1598-1600. Gravenhage: Martinus Nijhoff, 1923-1925. 
seria finalmente alcançado, mas uma forte tempestade dispersou a flotilha na noite de 8 de setembro, separando dos demais o "Geloof" e o "Trouwe" ("Fidelidade") - um vaso de 220 toneladas com 86 homens capitaneados por Baltazar de Cordes. Impelidas de volta ao Estreito em 26 de setembro, essas duas embarcações passariam de um ancoradouro ao outro na esperança de que o verão trouxesse uma mudança nos ventos e um tempo mais favorável. Culminando todos os infortúnios, o "Geloof" se perderia do "Trouwe" no dia 11 de dezembro de 1599, deixando Sebald de Weert entregue à própria sorte com uma equipagem exausta e muito propensa a exigir um retorno imediato para a Holanda. Na verdade, o "Geloof" jamais voltou a se reunir com o restante da esquadra, cujos navios terminaram capturados em águas inimigas ou naufragaram meses mais tarde.

Em 16 de dezembro de 1599, Sebald de Weert teve a grata surpresa de encontrar Olivier van Noort, o qual passava pelo Estreito de Magalhães em sua viagem de circunavegação (vide adiante). No entanto, o "Geloof" logo se mostrou incapaz de acompanhar as outras embarcações, circunstância que levaria De Weert a se despedir de Van Noort no dia 5 de janeiro de 1600 e iniciar sua volta para casa. Em 21 de janeiro, tendo carregado a carne de várias centenas de pingüins abatidos na "Ilha dos Pingüins" (para muitos a atual Isla Magdalena), o "Geloof" abandonou o Estreito de Magalhães, rumando para a costa da África. Após bordejar o norte do Arquipélago das Malvinas em 24 de janeiro, Sebald de Weert cruzaria a linha do Equador em 15 de março e avistaria o litoral da Guiné treze dias mais tarde, chegando à Inglaterra em 6 de julho. Em 13 de julho de 1600, o "Geloof" entraria no canal de Goeree com apenas 36 homens, pouco mais de um terço da tripulação original.

Durante os nove meses de permanência no Estreito de Magalhães e circunvizinhanças, Sebald de Weert travou diversas escaramuças com os indígenas da região, todos muito belicosos e arredios. Não obstante, em 10 de dezembro de 1599, a equipagem do "Geloof" conseguiu capturar uma mulher acompanhada de uma criança de quatro anos e um menino de apenas seis meses. Dois dias depois, essa mulher foi devolvida à praia com seu filho, mas a menina foi levada para a Holanda e morreu pouco tempo depois ${ }^{48}$. Parece razoável supor que a chegada dessa pri-

48 KERR, R. (Org.). A general history and collection of voyages and travels, arranged in systematic order forming a complete history of the origin and progress of navigation, discovery and commerce, by sea and land, from the earliest ages to the present time. Edinburgh \& London: W. Blackwood \& T. Cadell, 1824. 
sioneira despertasse grande interesse, pois as histórias fabulosas sobre os "gigantes" da Patagônia e Terra do Fogo havia anos circulavam pela Europa, constituindo uma das "maravilhas" presentes no imaginário quinhentista ${ }^{49}$. Baseada em testemunhos de aventureiros como Francis Drake, Pedro Sarmiento de Gamboa, Tomé Hernandez e Anthony Knivet ${ }^{50}$, essa lenda seria reafirmada por Sebald de Weert e seus comandados sem maiores alterações.

As vicissitudes de Sebald de Weert tornaram-se conhecidas graças ao relato de um dos seus companheiros de viagem - no caso Barent Jansz Potgieter, cirurgião do "Geloof”. Vinda à luz logo após o retorno da expedição ${ }^{51}$, essa narrativa causaria impacto nada desprezível, tendo sido objeto de pelo menos três outras edições entre 1617 e $1663^{52}$, além de marcar presença em algumas "coleções de viagens" seiscentistas ${ }^{53}$.

49 BURGHARTZ, S. Aneignungen des fremden: staunen, stereotype und zirkulation um 1600. In: HUWILER, E. \& WACHTER, N. (Org.). Integrationen des widerläufigen. Münster: Lit Verlag, 2004. p. 109-137. v. 3; MAGASICHAIROLA, J.; DE BEER, J.-M. America magica: quand l'Europe de la renaissance croyait conquérir le paradis. Paris: Autrement, 1994.

50 A. Knivet in HAKLUYT, R. The Principall Nauigations, Voiages, Traffiqves and Discoueries of the English Nation, made by Sea or ouer-land, to the remote, and farthest distant quarters of the Earth, on any time within the compasse of these 1500 yeeres. London: George Bishop, Ralph Newberie and Robert Barker, 1598-1600; DE IRIARTE, B. (Ed.). Viaje al Estrecho de Magallanes Por el Capitan Pedro Sarmiento de Gamboa En los años de 1579 y 1580 Y noticia de la expedicion Que despues hizo para poblarle. Madrid: Imprenta Real de la Gazeta, 1768; PURCHAS, S. Pvrchas his Pilgrimage. Or Relations of the World and the Religions Obserued in all Ages and places Discouered, from the Creation vnto this Present. Contayning a Theologicall and Geographicall Historie of Asia, Africa, and America, with the Islands adiacens. London: Willian Stansby, 1626.

51 POTGIETER, B. J. Wijdtloopigh Verhael van 'tgene de vijf Schepen (die int jaer 1598. tot Rotterdam toegherust werden, om door de Straet Magellana haren handel te dryven) wedervaren is, tot den 7. September 1599 toe, op welcken dagh Capiteijn Sebald de Weert, met twee schepen, door onweder vande vlote versteken werdt. Amsterdam: [Zacharias] Heijns, 1600.

52 SABIN, J. A dictionary of books relating to America, from its discovery to the present time. Amsterdam: N. Israel, 1961-1962; TIELE, P. A. Mémoire Bibliographique sur les Journaux des navigateurs néerlandais. Amsterdam: Frederik Muller, 1867.

53 Bem exemplificados por COMMELIN, I. Begin ende Voortgangh Vande Vereenigde Neederlantsche Geoctroyeerde Oost-Indische Compagnie. [Amsterdam: Jan Jansz], [ca. 1644]; SAEGHMAN, G. J. (Ed.). Verscheyde Oost-Indische Voyagien: Met de Beschrijvingen van Indien. Amsterdam: Gillis Joosten Saeghman, [ca. 1663-1670]. 
As nove gravuras encontradas na obra de Potgieter despertaram a atenção de vários autores e do próprio editor responsável - o poeta e escritor Zacharias Heyns - o qual não hesitou em reproduzir determinadas imagens dos nativos do Estreito de Magalhães no seu "Dracht-Thoneel" (Fig. 4), uma coletânea de ilustrações sobre os diferentes povos do mundo impressa no começo do século XVII ${ }^{54}$. Pouco depois, a viúva e os dois filhos de Theodore de Bry incluiriam o volume de Potgieter na nona parte das "Grand Voyages" $" 55$, utilizando diversos motivos encontrados nas pranchas da "Wijdtloopigh Verhael van "tgene de vijf Schepen" ("Relação circunstanciada do que ocorreu aos cinco navios") para compor novos arranjos por vezes muito diferentes dos originais (Fig. 4).

Ao contrário das imagens anteriores, essa imagem da "America" não parece guardar exata correspondência com nenhuma das gravuras pertencentes ao "Wijdtloopigh Verhael" ou às "Grand Voyages". De fato, canoas com uma fogueira acesa no interior só aparecem na quinta lâmina do livro de Potgieter ${ }^{56}$ e na vigésima segunda prancha dos De $\mathrm{Bry}^{57}$, estando sempre tripuladas por um ou dois homens adultos em nítida atitude belicosa, constituindo uma cena claramente distinta daquela elaborada por Jodocus Hondius inclusive por não haver qualquer presença feminina (Fig. 5).

Discrepâncias dessa natureza e a indiscutível escassez de fontes relativas aos indígenas do Estreito de Magalhães na Europa do século XVII ${ }^{58}$ sugerem a possibilidade de Jodocus

54 HEYNS, Z. Dracht-Thoneel: waer op het fatsoen van meest alle de Kleedren, soowel der gener diemen nu ter tyt de gansche Weirelt door dragende is, als de oude afgeleyde eygentlyck afgebeelt synde, ten thoon gestelt ende van wat natien die syn; met corte woorden in rym beschreven wordt. Amsterdam: [s.n.], [1601].

55 DE BRY, T. Americae Nona \& postrema Pars. Qva de ratione elementorvm: de Novi Orbis natvra: de hvivs incolarvm svperstitiosis cultibus: deq ; forma Politiae ac Reipubl. ipsorum copiosè pertractatur. Francoforti ad Moenum: Matth[aus] Beckervm, 1602.

56 POTGIETER, B. J. Wijdtloopigh Verhael van 'tgene de vijf Schepen (die int jaer 1598. tot Rotterdam toegherust werden, om door de Straet Magellana haren handel te dryven) wedervaren is, tot den 7. September 1599 toe, op welcken dagh Capiteijn Sebald de Weert, met twee schepen, door onweder vande vlote versteken werdt. Amsterdam: [Zacharias] Heijns, 1600.

57 DE BRY, T. op. cit.

58 COOPER, J. M. Analitycal and critical bibliography of the tribes of Tierra del Fuego and adjacent territory. Bureau of American Ethnology Bulletin, Washington, n. 63, p. 1-233, 1917. 
Hondius ter criado uma composição própria a partir de elementos passiveis de serem observados tanto nas estampas de Potgieter quanto naquelas dos De Bry, não havendo como definir qual das duas teria servido de modelo. De fato, o episódio da captura da mulher com duas crianças e do posterior seqüestro da jovem menina alakaluf - uma das passagens mais marcantes da viagem de Sebald de Weert - talvez levasse Hondius a incluir uma figura materna em sua gravura, representação que poderia estar baseada tanto na lâmina da mulher com duas crianças encontrada no livro de Potgieter quanto na versão fragmentária impressa pelos De Bry (Fig. 4). Na verdade, o livro de Potgieter parece ter inspirado outras licenças artísticas desse tipo, haja vista não existir qualquer correspondência entre as figuras originais do "Wijdtloopigh Verhael" e a vigésima segunda prancha das "Grand Voyages" na qual, sob o significativo título de "Os holandeses perto da ilha, no Estreito de Magalhães, onde encontraram homens grandes e portentosos" ("Hollandi in Freto Magellanico iusta insulam quandam grandes \& portentosos homines inveniunt"), os De Bry retratam um dos combates mantidos entre os europeus e os "gigantescos" indígenas locais (Fig. 5).

\subsection{Junco japonês}

Localizada ao sul do mítico "Estreito de Amian", a quarta gravura alcança 60x45 $\mathrm{mm}$ e representa um junco de dois mastros armados com uma única vela quadrangular de cordame bem evidente. A bombordo, nota-se a presença de um comprido remo espatulado, enquanto a proa abriga uma grande âncora pontiaguda de tamanho muito superior ao das seis figuras humanas indefinidas presentes no convés (Fig. 6). Escrita em um cartucho decorado adjacente, uma sentença latina afirma ser esta uma "variedade de navio do Japão, com velas de caniços e âncora de madeira" ("Navigij genus ex I. Iaponia velis ex arundine contextis ligneisque anchoris").

Embora um tanto grosseira, a imagem em foco pretende retratar um junco, embarcação típica do Oriente empregada tanto na guerra quanto no comércio. A julgar pela legenda anexa e o período considerado, este poderia ser um dos famosos "navios do selo vermelho" ("shuinsen") existentes no começo do domínio Tokugawa, vasos que navegavam mediante licença (o "selo vermelho") especialmente concedida e eram responsáveis por todo comércio regular mantido entre o Japão e o restante da Ásia. Ativo na primeira metade do século XVII, esse sistema de patentes contemplava famílias tradicionais de mercadores e certos favoritos do Xógum, tendo chegado a 
envolver centenas de unidades armadas capazes de atingir as Filipinas, Tailândia e até mesmo a Índia. Oscilando entre 500 e 750 toneladas, alguns desses juncos podiam equiparar-se aos galeões, contando com uma tripulação de aproximadamente 200 homens. Os "shuinsen" permaneceriam em atividade até 1635, quando a política dos Tokugawa de restringir os contatos entre japoneses e europeus levou à proibição das viagens marítimas, ato que favoreceu sobretudo os holandeses da Companhia das Índias Ocidentais ${ }^{59}$.

Embora notícias sobre os juncos chineses tivessem chegado à Europa já no século XIII graças a Marco Polo e outros viajantes do medievo, esses barcos só vieram a ser melhor conhecidos com a expansão ultramarina de portugueses e espanhóis, conforme exemplifica o texto de Gaspar da Cruz (ca. 1570) ${ }^{60}$. Em comparação, os testemunhos quinhentistas oriundos de fontes protestantes revelam-se bem menos comuns, evidenciando o cuidado dos países ibéricos em preservar seu monopólio comercial com o Oriente. Talvez o mais notável desses relatos caiba a Jan Huygen van Linschoten, pois esse espião holandês conseguiu ocupar o cargo de secretário do Arcebispo de Goa entre 1583 e $1589^{61}$, posição privilegiada que lhe permitiu adquirir amplo conhecimento sobre os domínios portugueses na Ásia ${ }^{62}$.

Na esteira das viagens inglesas de Francis Drake e Thomas Cavendish, as Províncias Unidas não poupariam esforços na tentativa de disputar as fabulosas riquezas do Oriente com as potências ibéricas (vide acima). Entre os aventureiros a arriscar a sorte pela difícil rota do Estreito de Magalhães, Olivier van Noort destaca-se como o primeiro holandês e o quarto europeu a concluir com sucesso uma navegação ao redor do globo, tendo chegado às Filipinas e Insulíndia no final do

59 BOXER, C. R. The christian century in Japan 1549-1650. Berkley: University of California Press, 1951; . The Dutch seaborne empire 1600-1800. London: Hutchinson, 1965; NAGAZUMI, Y. [Red seal ships]. Tokyo: Japan Historical Society, 2001.

60 GASPAR DA CRUZ. Tractado em que se cõtam muito por estẽso as cousas da China, cõ suas particularidades, e assi do reyno d'Ormuz, cõposto por el R. padre frey Gaspar da Cruz da ordẽ de sam Domingos. Evora: Andre de Burgos, [ca. 1570].

61 PARR, C. M. Jan van Linschoten: the Dutch Marco Polo. New York: Thomas Y. Crowell, 1964.

62 LINSCHOTEN, J. H van. Reys-gheschrift vande navigatien der Portugaloysers in Orienten, inhoudende de Zee-vaert, so van Portugael nae Oost-Indien, als van Oost-Indien weder naer Portugael. Amstereldam: Cornelis Claesz, 1595; Itinerario, Voyage ofter schipvaert van Jan Huygen van Linschoten naer Oost ofte Portugaels Indien. Amstelredam: Cornelis Claesz, 1596. 
século XVI. Ávido por glórias e pelo ouro espanhol, Van Noort era um estalajadeiro de Utrecht atuante em Rotterdam que decidira se unir a três outros comerciantes, além de diversos associados menores, na formação de mais uma "companhia mercantil" ("rederij") interessada em abrir caminho para os tesouros das "Índias", prática usual nos Países Baixos.

Quatro navios foram armados com os 200.000 florins arrecadados de Peter van Bueren, Hugo Gerritz, John Bennick e demais investidores, cabendo aos sócios de Rotterdam equipar a capitânia "Mauricius" de 275 toneladas e um iate de 50 toneladas denominado "Eendracht" ("Concórdia"), enquanto aqueles de Amsterdam enviariam a sota-capitânia "Hendrik Frederik" de 350 toneladas e um segundo iate de 50 toneladas chamado "Hoop" ("Esperança"). Contando com cerca de 248 homens, a frota teve Olivier van Noort como almirante à frente do "Mauricius" e Jakob Claez van Ilpendam como vice-almirante no "Hendrik Frederik", ao passo que Pieter Esaiasz de Lint e Jakob Jansz Huidekoper comandariam o "Eendracht" e o "Hoop"63.

63 Para maiores detalhes, vide BARREVELD, D. J. De route om de West: Olivier van Noort, de eerste Nederlander die om de wereld zeilde. Epe: Niesje Wolters van Bemmel, 2000; BOXER, C. R. The Dutch seaborne empire 1600-1800. London: Hutchinson, 1965; BRUIJN, J.R.; GAASTRA, F. S.; SCHÖFFER, I. (Ed.). Dutch-Asiatic shipping in the 17th and 18th Centuries. The Hague: Martinus Nijhoff, 1979-1987; BURNEY, J. A Chronological History of Voyages of Discoveries in the South Sea or Pacific Ocean. London: Luke Hansard \& Sons, 1803-1817; LA GRAVIÈRE, J. de. Le Anglais et les Hollandais dans les mers polaires et dans la Mer des Indes. Paris: Plon, 1890; HARRIS, J. Navigantium atque Itinerantium Bibliotheca. London: T. Osborne, 1764; HOWGEG0, R. J. Encyclopedia of exploration to 1800. Potts Point: Hordern House, 2003; IJZERMAN, J. W. (Ed.). De reis om de wereld door Olivier van Noort 1598-1601. Gravenhage: Linschoten-Vereeniging, 1926; JAVET, I. Los primeros holandeses en el estrecho. Boletín de la Academia Chilena de la Historia, n. 26, p. 43-64, 1943; KERR, R. (Org.). A general history and collection of voyages and travels, arranged in systematic order forming a complete history of the origin and progress of navigation, discovery and commerce, by sea and land, from the earliest ages to the present time. Edinburgh \& London: W. Blackwood \& T. Cadell, 1824; MOLLEMA, J. C. De reis om de wereld van Olivier van Noort. 1598-1601. Amsterdam: P.N. van Kampen \&t Zoon, 1937. MORGA, A. de. Svcesos de las Islas Filipinas. Mexico: Geronymo Balli, 1609; SILVERBERG, R. The longest voyage: circumnavigators in the age of discovery. Athens: Ohio University Press, 1997; SLUITER, E. (Ed.). New light from Spanish archives on the voyage of Olivier van Noort: the Vice-Admiral Ship, the Hendrick Frederick, on the West Coast of the Americas (1660). The Hague: Martinus Nijhoff, 1937; SWART, F. The circumnavigation of the globe by Pieter Esaiasz de Lint, 1598-1603. The Journal of the Hakluyt Society. Disponivel em: www.hakluyt.com. Acesso em: 29 de junho de 2007; TAUNAY, A. de. Visitantes do Brasil Colonial (Seculos XVI-XVIII). São Paulo: Companhia Editora Nacional, 1933. 
Obtida a carta de corso do "Stadtholder" Maurits van Nassau, Príncipe de Orange, o "Mauricius" e o "Eendracht" deixaram Goeree em 13 de setembro de 1598, reunindo-se no caminho de Plymouth ao "Hendrik Frederik" e ao "Hoop", ambos vindos de Amsterdam. Após embarcar mais suprimentos e novos companheiros de aventura - entre os quais o experiente Capitão Melis, tripulante da primeira viagem de circunavegação de Thomas Cavendish - a esquadra largou do porto inglês em 21 de setembro de 1598, rumo à costa da África. 0 Arquipélago das Canárias foi alcançado em 6 de outubro e a costa da Guiné avistada em 3 de novembro de 1598. Sete dias mais tarde, os navios aportariam na ilha de Príncipe em busca de provisões e entraram em choque com os portugueses, escaramuça que custaria a vida de alguns tripulantes e do próprio Capitão Melis - perda irreparável para os planos de Van Noort. Abandonando o local em 17 de novembro de 1598, a expedição chegaria à ilha de Ano Bom em $1^{\circ}$ de janeiro de 1599, iniciando a travessia do Atlântico pouco tempo depois.

Ultrapassando o Cabo de São Tomé, litoral do Rio de Janeiro, em 5 de março de 1599, Van Noort atingiu a Baía de Guanabara em 9 de março do mesmo ano. Como a forte resistência dos habitantes impedia todas as tentativas de abastecimento, a flotilha dirigiu-se para o sul, fundeando na ilha de São Sebastião. Sem encontrar víveres capazes de combater os crescentes casos de escorbuto, os holandeses partiriam - no dia 17 de março de 1599 - em busca da ilha de Santa Helena, onde pretendiam invernar. Fracassando nessa tentativa pela inexperiência dos pilotos, a flotilha foi impelida de volta para a costa brasileira, alcançando uma pequena ilha no litoral do Rio de Janeiro em $1^{\circ}$ de junho de 1599. Durante os quinze dias necessários para recompor as forças da tripulação, o "Eendracht" começou a fazer água e teve de ser abandonado, desastre que levaria o antigo "Hoop" a ser renomeado em sua homenagem.

Em 16 de junho de 1599, a expedição partiu para Puerto Deseado, Argentina, trajeto concluído em 20 de setembro. Reconfortados pela grande abundância de gêneros - entre os quais a carne e ovos de milhares de pingüins - os viajantes só deixariam o local em 29 de outubro, entrando no Estreito de Magalhães em 25 de novembro de 1599. Além dos ventos contrários e tempestades, as limitações do próprio comando nos assuntos de marinharia fizeram que Van Noort tardasse mais de três meses em percorrer o Estreito, encontrando o desditado navio de Sebald de Weert durante sua passagem (vide acima). Ao atingir o Pacífico em 29 de fevereiro de 1600, a equipagem estaria reduzida a cerca de 147 almas, contingente destinado a sofrer novas defecções no dia 12 de março de 1600, quando 
o tempo borrascoso extraviou o "Hendrik Frederik" do restante da frota. Sob o comando de Pieter Esaiasz de Lint, a sota-capitânia dos flamengos encontraria seu próprio caminho para as Índias Ocidentais, encalhando na ilha de Ternate, Molucas, entre fevereiro e abril de 1601.

Desistindo de esperar pelo "Hendrik Frederik", o "Mauricius" e o "Eendracht" navegaram ao longo da costa do Chile, chegando até o Peru em busca de barcos espanhóis carregados de metais preciosos. Embora lograssem tomar dois vasos mercantes sem grande importância, os holandeses tiveram a sorte de escapar da força posta ao seu encalço por Luis de Velasco, Marquês de Salinas e Vice-Rei do Peru ${ }^{64}$. Em 10 de maio de 1600, Van Noort deixaria o litoral peruano rumo ao Oriente, passando pela "Ilha dos Ladrões" (atual Marianas) em 5 de setembro de 1600 e por Guam onze dias mais tarde, tomando rumo das Filipinas. Em 16 de outubro de 1600, os navios entraram no Estreito de São Bernardino, permanecendo à espera de ventos favoráveis e da eventual captura de uma embarcação com piloto ou mapas capazes de mostrar o caminho para $\mathrm{Ma}$ nila. Em 7 de novembro, os holandeses descobririam um junco chinês carregado de provisões para essa cidade, prosseguindo em seguida para a ilha de Mindoro. No dia $1^{\circ}$ de dezembro de 1600, ao largo de Luzon, os tripulantes avistaram seu primeiro junco proveniente do Japão - um navio de cinqüenta toneladas com formato peculiar que possuía velas feitas de caniços, âncoras de madeira e cabos de palha trançada ${ }^{65}$.

Em 14 de dezembro de 1600 aconteceria um confronto com dois navios espanhóis, pois as autoridades locais já haviam tomado conhecimento da presença de corsários inimigos nas Filipinas. No decorrer da batalha, o "Eendracht" foi capturado pelo "San Bartolome" - uma pequena embarcação de 50 toneladas sob as ordens de Juan de Alcega - mas o "Mauricius" conseguiria escapar do "San Diego" - um galeão mercante de aproximadamente 300 toneladas adaptado para o combate e liderado por Antonio de Morga. Após tomar a capitânia

64 GERHARD, P. Pirates of the Pacific 1575-1742. Lincoln: University of Nebraska Press, 1990.

65 NOORT, 0. van. Beschryvinghe van de Voyagie om den geheelen Werelt Cloot, ghedaen door Olivier van Noort van Vtrecht, Generael over vier Schepen, te weten: Mauritius als Admirael, Hendrick Frederick Vice-Admirael, de Eendracht, midtsgaders de Hope, op hebbende tsamen 248. man, om te zeylen door de Strate Magellanes, te handelen langs de Custen van Cica, Chili en Peru, om den gantschen Aerden Cloot, ende door de Molucques wederom thuys te comen. Amstelredam: Cornelis Claesz, 1602. 
flamenga de assalto, dominar o convés principal e encurralar os adversários na coberta, os combatentes do "San Diego" permaneceriam horas aguardando as ordens do comando, tendo finalmente a desagradável surpresa de ver seu barco fazer água e ir ao fundo em virtude dos danos sofridos durante a refrega.

Furtando-se de uma eventual perseguição, Van Noort escapou para o sul, chegando a Bornéu em 26 de dezembro de 1600. Após nove dias de estadia, o "Mauricius" tomaria o rumo do Cabo da Boa Esperança, alcançando o Atlântico na primeira semana de maio. Em busca dos suprimentos necessários, o capitão holandês realizou uma curta escala na ilha de Santa Helena entre 26 e 30 de maio de 1601, navegando em seguida para o norte. Depois de cruzar a linha do Equador em 14 de junho, os flamengos contornariam o Arquipélago dos Açores em 1을 de agosto de 1601, atingindo o litoral da Inglaterra 17 dias mais tarde. Ao meio dia de 26 de agosto de 1601, após quase três anos de viagem, o "Mauricius" chegaria a Rotterdam trazendo apenas 45 tripulantes.

Apesar de constituir um inegável fiasco econômico, a viagem de circunavegação concluída pelo "Mauricius" transformaria Olivier van Noort em um autêntico herói nacional, cujos feitos engrandeciam a Holanda em um momento delicado de guerra aberta contra a Espanha e forte disputa por domínios ultramarinos ${ }^{66}$. Face às circunstâncias, não surpreende que o capitão flamengo se aproveitasse dessa boa sorte para - ao contrário dos casos anteriores - preparar seu próprio relato de todos os eventos, publicando um primeiro "Extract" em holandês trinta dias após o retorno do "Mauricius"67. 0 texto integral foi lançado no ano seguinte ${ }^{68}$ com traduções para o

66 SCHMIDT, B. Innocence abroad: the Dutch imagination and the New World, 1570-1670. Cambridge: Cambridge University Press, 2001.

67 NOORT, 0. van. Extract oft Kort Verhael wt het groote Journael vande wonderlicjcke ende groote reyse ghedaen door de strate Magellana en Landen by den E. Olivier van Noort, Admirael en General vande vier Schepen toegerust tot Rotterdam Ao 1598. Rotterdam: Jan van Waesberghe, 1601.

68 Idem. Beschryvinghe van de Voyagie om den geheelen Werelt Cloot, ghedaen door Olivier van Noort van Vtrecht, Generael over vier Schepen, te weten: Mauritius als Admirael, Hendrick Frederick Vice-Admirael, de Eendracht, midtsgaders de Hope, op hebbende tsamen 248. man, om te zeylen door de Strate Magellanes, te handelen langs de Custen van Cica, Chili en Peru, om den gantschen Aerden Cloot, ende door de Molucques wederom thuys te comen. Amstelredam: Cornelis Claesz, 1602. 
francês e o alemão, havendo registro de uma segunda tiragem em holandês presumivelmente dessa mesma época. Entre 1610 e 1684, a narrativa de Van Noort receberia mais uma versão francesa e pelo menos nove outras impressões em holandês ${ }^{69}$.

Desde a edição integral de 1602, o livro de Olivier van Noort seria enriquecido com 25 gravuras de cobre de autoria de Baptista van Doetechum, renomado artífice da época ${ }^{70}$. Incluída em diversas "coleções de viagens" de autores seiscentistas $^{71}$, a "Beschryvinghe van de Voyagie om den geheelen Werelt Cloot" ("Descrição da viagem em torno do mundo") também faria parte do nono volume das "Grand Voyages", embora a viúva e os dois filhos de Theodore de Bry fornecessem uma variante bastante resumida do texto e figuras por vezes bem distintas das originais ${ }^{72}$.

Entre as 25 pranchas da "Beschryvinghe van de Voyagie om den geheelen Werelt Cloot”, a décima sétima retrata um junco japonês de velas quadrangulares virtualmente idêntico àquele representado na "America". A mesma embarcação, entretanto, foi reproduzida pelos De Bry na décima terceira prancha dedicada à viagem de Van Noort, a qual veio à luz sob o título de "Batalha naval entre os holandeses e espanhóis diante de Manila" ("Holandorum cum Hispanis ante Manillan pugna navalis"). Embora ambas as fontes possam ter servido de inspiração para Jodocus Hondius, a gravura de Doetechum talvez constitua a alternativa mais provável pela disposição das diminutas figuras humanas presentes no convés (Fig. 6).

A exemplo da maioria dos casos anteriores, Jodocus Hondius desprezou os elementos secundários da composição de Doetechum para construir uma imagem especular bastante

69 SABIN, J. A dictionary of books relating to America, from its discovery to the present time. Amsterdam: N. Israel, 1961-1962; TIELE, P. A. Mémoire Bibliographique sur les Journaux des navigateurs néerlandais. Amsterdam: Frederik Muller, 1867.

70 TIELE, P. A. op.cit.

71 Bem exemplificados por COMMELIN, I. Begin ende Voortgangh Vande Vereenigde Neederlantsche Geoctroyeerde Oost-Indische Compagnie. [Amsterdam: Jan Jansz], [ca. 1644]; SAEGHMAN, G. J. (Ed.). Verscheyde Oost-Indische Voyagien: Met de Beschrijvingen van Indien. Amsterdam: Gillis Joosten Saeghman, [ca. 1663-1670].

72 DE BRY, T. Americae Nona \& postrema Pars. Qva de ratione elementorvm: de Novi Orbis natvra: de hvivs incolarvm svperstitiosis cultibus: deq ; forma Politiae ac Reipubl. ipsorum copiosè pertractatur. Francoforti ad Moenum: Matth[aus] Beckervm, 1602. 
simplificada do detalhe escolhido (Fig. 6). Sem embargo, o comentário em latim relativo à gravura da "America" ("Navigij genus ex I. Iaponia velis ex arundine contextis ligneisque anchoris") não guarda qualquer relação com o texto referente à lâmina original da "Beschryvinghe van de Voyagie om den geheelen Werelt Cloot", pois Van Noort limita-se a observar em francês e holandês - ser este "um barco japonês chamado Sampana" ("Ung Batteau de Japan düt Champan" e "Eeen Schip oft Champan uyt Japon"). Por outro lado, a frase de Hondius recorda sobremaneira a legenda de uma das estampas do célebre "Itinerario" de Jan Huygen van Linschoten ${ }^{73}$, ilustração que mostra um junco de aspecto bastante diverso acompanhado da sentença "Navios da China e Java com velas de caniço, cordame trançado e âncora de madeira" escrita em latim ("Naves e China et Java velis ex arundine contextis et anchoris ligneis" (Fig. 6).

\subsection{Festejo tupinambá}

Estendendo-se pelo vazio do Pacífico Sul, essa gravura foi enquadrada em um grande cartucho decorado com 224x67 mm que oculta boa parte de uma vasta "Terra Australis" de limites indefinidos ${ }^{74}$. Trata-se da maior e mais conspícua de todas as "cenas de costumes" presentes na "America", abarcando nada menos de 13 figuras humanas distintas - cinco homens e oito mulheres - envolvidas em um curioso festejo (Fig. 7). Disposta ao longo da borda superior do cartucho, uma longa sentença em latim esclarece ser esse o

modo de preparar e tomar a bebida entre os [nativos] americanos no Brasil, onde as virgens - logo depois que mastigam as raizes - cospem-nas, em seguida cozinhando-as em potes e oferecendo-as aos homens para que eles bebam. Essas bebidas especiais são consideradas deliciosas entre eles ("Modus conficiendi \& bibendi potum apud Americanos in Brasilia, ubi virgines postquam radices quasdam manducarunt, rursus expuunt,

73 LINSCHOTEN, J. H. van. Itinerario, Voyage ofter schipvaert van Jan Huygen van Linschoten naer Oost ofte Portugaels Indien. Amstelredam: Cornelis Claesz, 1596.

74 Vide também KRETSCHMER, K. Historia de la geografía. Barcelona: Editorial Labor, 1942. 
deinde ollis coquunt \& viris bibendum praebent. Atque haec potatio praecipuus sunt apud cos diliciae").

Logo em seguida, uma segunda frase estabelece a autoria de Jodocus Hondius e designa Amsterdam como local de execução do trabalho ("Jodocus Hondius excudit Amsterodami").

Entre todas as imagens examinadas até o momento, nenhuma outra possui um vínculo tão evidente com as "Grand Voyages", detalhe que pode ter exercido considerável influência na freqüente atribuição da coletânea de Theodore de Bry como fonte das ilustrações encontradas na "America"75. De fato, este detalhe está claramente baseado no terceiro livro das "Grand Voyages"76 e constitui mera adaptação da estampa referente ao capítulo XV, o qual descreve como os índios do Brasil preparam "as bebidas com as quais se embriagam e de que maneira recebem os companheiros de bebedeira" ("De modo praeparandi potiones, quibus inebriantur, \& de moribus inter compotandum receptis"). Na verdade, a prancha em questão mostra 23 nativos envolvidos no preparo e consumo do cauim, beberagem fermentada de mandioca, milho, batata doce etc. muito comum entre os tupis do Brasil Oriental ${ }^{77}$. Tal como nos casos anteriores, Jodocus Hondius descartou vários elementos da composição original para construir uma imagem especular bastante simplificada do modelo escolhido, versão que inclui apenas 13 indígenas redistribuídos em um novo arranjo. Haveria certa tendência em preservar os motivos mais representativos, enquanto os secundários ou repetidos acabariam eliminados (Fig. 7).

A julgar pelo título, o terceiro livro das "Grand Voyages" buscou reproduzir as atribulações vividas por Hans Staden no Brasil (1550-1554) tendo como base a célebre "Warhaftige His-

75 Um bom exemplo nesse sentido pode ser dado por BURDEN, P. D. The mapping of North America: a list of printed maps 1511-1670. Rickmansworth: Raleigh Publications, 1966.

76 DE BRY, T. Americae Tertia Pars. Memorabilẽ Provinciae Brasiliae Historiam continẽs, germanico primium sermone scriptam à Ioãne Stadio Homburgensi Helso, nunc autem latinitate donatam à Teucrio Annaeo Priuato Colchante Po: \& Med: Addita est Narratio profectionis Ioannis Lerij in eamdem Provinciam, quã ille initio gallicè conscripsit, postea verò Latinam fecit. Francofurte: Theodori de Bry, 1592.

77 A. Métraux in STEWARD, J. H. (Ed.). Handbook of South American Indians. v. 3: The tropical forest tribes. Bureau of American Ethnology Bulletin, n. 143, p. 1-986, 1948; VENÂNCIO, R. P.; CARNEIRO, H. (Org.). Álcool e drogas na história do Brasil. São Paulo: Alameda, 2005. 
toria”, obra de 1557 que dispensa maiores comentários ${ }^{78}$. Como referência adicional, os De Bry empregariam a "Histoire d'un voyage fait en la terre du Bresil” da autoria de Jean de Léry, pastor protestante e companheiro do Almirante François Villegagnon na fracassada tentativa de fundar uma colônia francesa na Baía de Guanabara (1555-1567), episódio muitíssimo bem conhecido do público brasileiro ${ }^{79}$. Ambos os relatos receberiam uma entusiástica acolhida por parte do público quinhentista, pois o texto de Staden alcançou uma segunda edição já no seu primeiro ano de existência ${ }^{80}$, tendo obtido mais duas tiragens em alemão e três traduções para o holandês antes da virada do século. Lançada poucas décadas mais tarde, a obra de Léry cumpriu trajetória semelhante ${ }^{81}$, havendo notícia de pelo menos

78 STADEN, H. Warhaftige Historia vnd beschreibung eyner Landtschafft der Wilden, Nacketen, Grimmigen Menschfresser Leuthen, in der Newenwelt America gelegen, vor vnd nach Christi geburt im Land zũ Hessen vnbekant, biss vff dise ij. nechst vergangene jar, Da sie Hans Staden von Homberg auss Hessen durch sein eygne erfarung erkant, vnd yetzo durch den truck an tag gibt. Marpurg: Andress Kolben, 1557.

79 Para maiores detalhes, consulte-se FRAGOSO, A. T. Os franceses no Rio de Janeiro. Rio de Janeiro: Biblioteca do Exército Editora, 1965; GAFFAREL, P. Histoire du Brésil Français. Paris: Maisonneuve, 1878; HOWGEG0, R.J. Encyclopedia of exploration to 1800. Potts Point: Hordern House, 2003; MARIZ, V. (Org.). Brasil-França: relações históricas no período colonial. Rio de Janeiro: Biblioteca do Exército Editora, 2006; MARIZ, V.; PROVENÇAL, L. Villegagnon e a França Antártica: uma reavaliação. Rio de Janeiro: Nova Fronteira \& Biblioteca do Exército Editora, 2000; PALAZZO, C. L. Entre mitos, utopias e razão: os olhares franceses sobre o Brasil (séculos XVI a XVIII). Porto Alegre: Editora da Pontifícia Universidade Católica do Rio Grande do Sul, 2002; STADEN, H. The captivity of Hans Stade of Hesse, in A.D. 15471555, among the Wild tribes of Eastern Brazil. London: Hakluyt Society, 1874; _. Brasilien: die wahrhaftige historie der wilden, nackten, grimmigen menschenfresserleute 1548-1555. Tübingen: Erdmann, 1982.

80 STADEN, H. Warhaftige Historia vnd beschreibung eyner Landtschafft der Wilden, Nacketen, Grimmigen Menschfresser Leuthen, in der Newenwelt America gelegen, vor vnd nach Christi geburt im Land zũ Hessen vnbekant, biss vff dise ij. nechst vergangene jar, Da sie Hans Staden von Homberg auss Hessen durch sein eygne erfarung erkant, vnd yetzo durch den truck an tag gibt. Marpurg: Andress Kolben, 1557; STADEN, H. Warhaftige beschreibung eyner Landtschafft der Wilden nacheten, grimmigen menschenfresser leuthen, in der newen welt America gelegen. Vor vnd nach Christi geburt im land zu Hessen vnbekant, biss vff dise zwey negst vergangene jar, Da sie Hans Staden von Homberg auss Hessen durch sein eygne erfarung erkant, vnd ytzt durch den truck an tag gibt. Marpurg: Andres Colben, 1557.

81 LÉRY, J. de. Histoire d'vn voyage fait en la terre dv Bresil, avtrement dite Amerique. La Rochelle: Antoine Chuppin, 1578. 
seis edições francesas, uma tradução holandesa e duas versões latinas impressas até $1600^{82}$.

Embora mantenham as xilogravuras originais de Hans Staden como eixo principal, as ilustrações preparadas por Theodore de Bry para o terceiro livro das "Grand Voyages" surgem como autênticos mosaicos resultantes de múltiplas influências. Contrariando possiveis expectativas, os motivos oriundos da obra de Léry não ocupam uma posição de relevo capaz de ombrear-se com figuras extraídas das "Singularitez de la France Antarctique" de André Thevet, religioso franciscano e futuro cosmógrafo do Rei de França que também viajou com Villegagnon para o Brasil (vide acima). Possuindo algumas das mais belas xilogravuras do seu tempo, o livro de Thevet despertou o interesse geral, tendo obtido mais duas impressões em francês logo após sua publicação em $1557^{83}$, além de duas versões em italiano e uma em inglês entre 1561 e $1600^{84}$. Um bom exemplo do papel exercido na coletânea de Theodore de Bry pode ser conferido pela supracitada ilustração das "Grand Voyages", pois essa prancha não só mostra um traço semelhante ao das estampas de Thevet como agrega alguns motivos extraídos das "Singularitez de la France Antarctique" - por exemplo aquele das mulheres cuspindo raízes de mandioca mastigadas em um tacho - diferindo bastante do original de Hans Staden no qual estaria calcada (Fig. 7 e 8).

Apesar de não participarem de fato da "cena de costumes" composta por Jodocus Hondius, tanto a arara (Psittacidae) quanto o tucano (Ramphastidae) que ornamentam o cartucho marcam presença como dois elementos exóticos indubitavelmente associados ao continente americano. Com efeito, os psitácidas do Novo Mundo chegariam à Europa logo após a viagem de Colombo, fato bem demonstrado pelas três araras-vermelhas - Ara macao (Linnaeus, 1758) - retratadas sobre o litoral brasileiro no famoso "Planisfério de Cantino" (1502) e pela imagem de uma outra arara-vermelha não identifi-

82 MORAES, R. B. de. Bibliographia Brasiliana: rare books about Brazil published from 1504 to 1900 and works by Brazilian authors of the Colonial Period. Los Angeles \& Rio de Janeiro: University of California Press \& Livraria Kosmos Editora, 1983; SABIN, J. A dictionary of books relating to America, from its discovery to the present time. Amsterdam: N. Israel, 1961-1962.

83 THEVET, A. Les singvlaritez de la France Antarctique, avtrement nommée Amerique: \& de plusieurs Terres \& Isles decouuertes de nostre temps. Paris: Maurice de la Porte, 1557.

84 MORAES, R. B. de. op.cit. 
cada presente no "Retrato do Casal Cuspinian", díptico de Lucas Cranach pintado em Viena entre 1502 e $1503^{85}$. Mesmo não gozando da mesma popularidade, os tucanos também foram levados para a Europa já em meados do século XVI, havendo vários registros sobre despojos existentes nos "gabinetes de curiosidades" da época ${ }^{86}$.

Malgrado a estilizada arara de Hondius possa ter origem em uma das pranchas do terceiro livro das "Grand Voyages" na verdade a lâmina referente ao capítulo XXII (Fig. 9) - cumpre estabelecer que Theodore de Bry jamais chegou a representar qualquer tucano, embora descreva essa ave no terceiro livro das "Grand Voyages" 87 . A julgar pela silhueta desproporcional bastante característica, o pequeno tucano $(22 \times 26 \mathrm{~mm}$ versus $54 \times 12$ $\mathrm{mm}$ da arara) representado por Jodocus Hondius estaria baseado no "Toucan" pertencente a uma segunda obra de André Thevet, no caso a célebre "Cosmographie Universelle"88 (Fig. 9).

\section{Os animais marinhos, monstros e navios europeus}

\subsection{Animais marinhos}

Variando entre $24 \times 9$ e 22x12 mm, três das quatro imagens disponíveis de "animais marinhos" tratam de "peixes-voadores”, categoria assaz curiosa por incluir tanto os verdadeiros representantes desse grupo (Exocoetidae) quanto os coiós (Dactylopteridae), peixes bentônicos pouco ativos que se mostram incapazes de voar, malgrado possuam nadadeiras

85 GEORGE, W. Animals on maps. London: Secker and Warburg, 1969; SICK, H. Brasilianischer Ara 1502/03 in Europa gemalt. Journal für Ornithologie, n. 125(4), p. 479-481, 1984; TEIXEIRA, D. M.; PAPAVERO, N. Os Animais do Descobrimento: a fauna brasileira mencionada nos documentos relativos à viagem de Pedro Álvares Cabral (1500-1501). Publicações Avulsas do Museu Nacional, n . 111, p. 1-133, 2006.

86 BELON, P. L'Histoire de la Natvre des Oyseaux, avec levrs descriptions, \& naïfs portraicts. Paris: Guillaume Cauellat, 1555.

87 DE BRY, T. Americae Tertia Pars. Memorabile Provinciae Brasiliae Historiam continẽs, germanico primium sermone scriptam à Ioãne Stadio Homburgensi Helso, nunc autem latinitate donatam à Teucrio Annaeo Priuato Colchante Po: \& Med: Addita est Narratio profectionis Ioannis Lerij in eamdem Provinciam, quã ille initio gallicè conscripsit, postea verò Latinam fecit. Francofurte: Theodori de Bry, 1592.

88 THEVET, A. Cosmographie Vniverselle d'André Thevet Cosmographe dv Roy. Paris: Pierre l'Huillier, 1575. 
peitorais muito expandidas formando amplas "asas" membranosas empregadas para afastar predadores e/ou escavar o fundo em busca de alimento ${ }^{89}$. Em comparação, os autênticos peixes-voadores (Exocoetidae) utilizam o impulso conferido por vigorosos movimentos da cauda para sair da água com grande velocidade e planar até $300 \mathrm{~m}$ sobre a superfície, sendo sustentados no trajeto por suas longas nadadeiras peitorais mantidas abertas e rígidas ${ }^{90}$.

Das sete variedades existentes de coiós, apenas Dactylopterus volitans (Linnaeus, 1758) ocorre no Atlântico, tendo sido assinalado da Inglaterra e leste dos Estados Unidos até Angola e Argentina. Essa espécie vive nos fundos arenosos e lodosos até os $80 \mathrm{~m}$ de profundidade, ao passo que os cerca de 65 Exocoetidae conhecidos costumam ser encontrados bem longe da costa, freqüentando a superfície de todos os oceanos tropicais e subtropicais do globo. Em geral, os registros de peixesvoadores efetuados ao largo do litoral europeu pertencem a Cheilopogon exsiliens (Linnaeus, 1771) - representante pelágico que acompanha as águas quentes da Corrente do Golfo e da Corrente do Atlântico Norte - enquanto uma população isolada de Cheilopogon heterurus (Rafinesque, 1810) habita as áreas neríticas do Mediterrâneo ocidental e chega ocasionalmente ao Atlântico Norte na Noruega e Dinamarca ${ }^{91}$.

Notícias imprecisas sobre peixes-voadores poderiam estar na origem do "serra", um fabuloso peixe de tamanho gigantesco e asas emplumadas descrito por Alberto Magno e tantas outras fontes do medievo ${ }^{92}$. De qualquer forma, os relatos acerca de peixes capazes de voar exerceram um poderoso fascínio nos autores dos séculos XVI e XVII, os quais acabariam por estender ao comuníssimo Dactylopterus volitans a mesma habilidade dos

89 CARPENTER, K. E. (Ed.). The living marine resources of the Western Central Atlantic. Rome: Food and Agriculture Organization of the United Nations, 2002. v. 2: Bony fishes part 1 (Acipenseridae to Grammatidae)

90 BREDER, C. M. A contribution to the life histories of Atlantic Ocean flyingfishes. Bulletin of the Bingham Oceanography Collection, n. 6 (5), p. 1-126, 1938; BRUUN, A. F. Flying-fishes (Exocoetidae) of the Atlantic. Dana Report, n. 6, p. 1-106, 1935.

91 CARPENTER, K. E. op. cit

92 KITCHELL JUNIOR, K. F.; RESNICK, I. M. (Org.). Albertus Magnus On Animals: a medieval summa zoologica. Baltimore: Johns Hopkins University Press, 1999; MERMIER, G. R. (Org.). A medieval book of beasts: Pierre de Beauvais' bestiary. Lewiston: Edwin Mellen Press, 1992; WHITE, T. H. (Ed.). The book of beasts: being a translation from a Latin bestiary of the twelfth century. New York: G.T. Putnam, 1954. 
Exocoetidae, equívoco destinado a prolongar-se até os dias de hoje. Apesar de os estudiosos do Renascimento não desconhecerem Cheilopogon heterurus ${ }^{93}$, os peixes-voadores tropicais despertaram enorme interesse, sendo considerados autênticos "prodígios" dignos da atenção de cosmógrafos, cronistas, médicos e cartógrafos renomados ${ }^{94}$.

0 primeiro dos três peixes-voadores retratados na "America" se encontra demasiado estilizado para permitir qualquer conclusão, mas o segundo não passa de um exemplar de Dactylopterus volitans com as nadadeiras peitorais meio estendidas, imagem quiçá extraída da prancha intitulada "Pisces in mari alati" ("Peixes alados no mar") pertencente ao quarto livro das "Grand Voyages" 95 (Fig. 10). Dizendo respeito a um Exocoetidae, a terceira ilustração poderia constituir, em última instância, uma cópia bastante grosseira de qualquer gravura sobre esses animais publicada pelos naturalistas e cronistas do período $^{96}$ (Fig. 10).

93 Por exemplo GESNER, K. Historiae Animalium Liber III qui est de Piscium \& Aquatilium Animantium natura. Tigvri: Christoph. Froschovervm, 1558; RONDELET, G. Libri de Piscibus Marinis, in quibus verae Piscium effigies expressae sunt: quae in tota Piscium historia contineantur, indicat Elenchus pagina nona et decima: Postremó accesserunt Indices necessarii. Lvgdvni: Mathiam Bonhomme, 1554-1555.

94 Exemplos nesse sentido podem ser observados nos trabalhos de LINSCHOTEN, J. H. van. Itinerario, Voyage ofter schipvaert van Jan Huygen van Linschoten naer Oost ofte Portugaels Indien. Amstelredam: Cornelis Claesz, 1596; ORTELIUS, A. Theatrum Orbis Terrarum. Antverpiae: Egidius Coppens, 1570; OVIED0 y VALDEZ, G. F. De la segunda parte de la general historia delas Indias. Valladolid: Francisco Fernandez de Cordoua, 1557; PARÉ, A. Les Oevvres d'Ambroise Paré, Conseiller, et Premier Chirvrgien du Roy. Paris: Gabriel Buon, 1585; THEVET, A. Cosmographie Vniverselle d'André Thevet Cosmographe $d v$ Roy. Paris: Pierre l'Huillier, 1575.

95 DE BRY, T. Americae Pars Qvarta. Sive, Insignis \& Admiranda Historia de reperta primùm Occidentali India à Christophoro Columbo Anno M.CCCCXCII Scripta ab Hieronymo Bezono Mediolanense, qui istic ãnis XIIII versatus, diligẽter omnia observavit. Francofurte: Theodoro de Bry, 1594.

96 Por exemplo em DE BRY, T. Americae Pars VIII. Continens Primo, descriptionem trivm itinervm nobilissimi et fortissimi Eqvitis Francisci Draken, qvi peregrato primvm Universo Terrarvm Orbe, postea cum nobilissimo Eqvite Iohanne Havckens, ad expugnandum ciuitatem Panama, in Indiam nauigauit, vbi vitam suam ambo finierunt. Francofurte: Theodorici de Bry Viduae $\mathrm{Ct}$ filiorum, 1599; RONDELET, G. op.cit. ; THEVET, A. Cosmographie Vniverselle d'André Thevet Cosmographe dv Roy. Paris: Pierre l'Huillier, 1575. 
Com não mais de $11 \times 9 \mathrm{~mm}$, um quarto detalhe mostra a cabeça de um tubarão-martelo (Sphyrna sp.) surgindo das ondas (Fig. 11), ocorrência nada excepcional considerando o vasto folclore construido em torno dos tubarões e o aspecto peculiar dos Sphyrnidae. Com ampla distribuição nos mares temperados e tropicais, os tubarões-martelo podem chegar a $6 \mathrm{~m}$ de comprimento, freqüentando sobretudo águas costeiras e áreas adjacentes da plataforma continental. Das dez espécies descritas, Sphyrna zygaena (Linnaeus, 1758) é uma das mais comuns, tendo sido registrada no litoral europeu desde as Ilhas Britânicas até a Península Ibérica e o Mediterrâneo ${ }^{97}$. Apesar de terem despertado a curiosidade de cronistas como Thevet ${ }^{98}$, os tubarõesmartelo não constituíam nenhuma novidade para naturalistas do Renascimento como Gesner e Rondelet, cuja obra "Libri de Piscibus Marinis" fornece uma ilustração capaz de lembrar a gravura de Hondius em mais de um aspecto $^{99}$ (Fig. 11).

\subsection{Seres monstruosos e navios europeus}

Com 17x12 mm e 17x9 mm, duas das três estampas referentes aos seres monstruosos pretendem retratar simples baleias (Cetacea), uma das quais liberando seu jorro através de um desmesurado espiráculo (Fig. 12). Cercados por mistério e uma impressionante variedade de lendas ${ }^{100}$, esses gigantescos mamiferos marinhos ocuparam um lugar de destaque no imaginário cristão e foram representados de forma muito pouco realista nos obras e cartas d'antanho, cujas ilustrações transformariam

97 COMPAGNO, L. J. V. FAO species catalogue. Sharks of the world: an annotated and illustrated catalogue of shark species known to date. Part 2. Carcharhiniformes. FAO Fisheries Synopsis No 125, n. 4 (part 2), p. 251-655, 1984.

98 THEVET, A. Les singvlaritez de la France Antarctique, avtrement nommée Amerique: \& de plusieurs Terres \& Isles decouuertes de nostre temps. Paris: Maurice de la Porte, 1557.

99 GESNER, K. Historiae Animalium Liber III qui est de Piscium \& Aquatilium Animantium natura. Tigvri: Christoph. Froschovervm, 1558; RONDELET, G. Libri de Piscibus Marinis, in quibus verae Piscium effigies expressae sunt: quae in tota Piscium historia contineantur, indicat Elenchus pagina nona et decima: Postremò accesserunt Indices necessarii. Lvgdvni: Mathiam Bonhomme, 1554-1555.

100 Vide EDEN, P. T. Theobaldi “Physiologus”. Leiden \&t Köln: E.J. Brill, 1972; WENDT, H. Auf Noahs Spuren: Die Entdeckung der Thiere. Hamm: C. Grote, 1956. 
os cetáceos em bestas prodigiosas quase irreconhecíveis aos olhos atuais ${ }^{101}$. No entanto, imagens desse feitio tornar-se-iam um motivo recorrente nos mapas, cosmografias e textos dos séculos XVI, sendo adotadas por autores como Adrien Coenen ${ }^{102}$, Gesner, Münster, Olaus Magnus ${ }^{103}$ e incontáveis cartógrafos do período ${ }^{104}$. Não deve causar surpresa, portanto, que a mais disforme das baleias de Jodocus Hondius recorde sobremaneira um dos exemplares de "cete" pertencentes à já mencionada “Carta Marina” de Olaus Magnus ${ }^{105}$ (Fig. 12).

$\mathrm{Na}$ acepção do termo ${ }^{106}$, o único "monstro" figurado por Jodocus Hondius foi descrito no segundo volume da "Cosmographie Universelle" de André Thevet, narrativa reproduzida anos depois nas publicações sobre "monstros e prodígios" do cirurgião Ambroise Paré. Grosso modo, esse estranho "peixe semelhante a um ganso" possuiria o "pescoço comprido" e um "corpo sem escamas provido de quatro nadadeiras no ventre", habitando os "mares da ilha de Hispaniola" onde era chamado de "aloes" pelos nativos ${ }^{107}$ (Fig. 13). Tal avantesma despertou

101 COHAT, Y. Vie et mort des baleines. Paris: Gallimard, 1986; JENKINS, J.

T. A history of the whale fisheries, from the Basque fisheries of the tenth century to the hunting of the finner whale at the present date. London: H.F. \& G. Witherby, 1921.

102 A. Coenen in EGMOND, F.; MANSON, P. (Ed.). The whale book: whales and other marine animals as described by Adrien Coenen in 1585. London: Reaktion Books, 2003.

103 GESNER, K. Historiae Animalium Liber III qui est de Piscium \& Aquatilium Animantium natura. Tigvri: Christoph. Froschovervm, 1558; MÜNSTER, S. Cosmographiae uniuersalis Lib[ri] VI. in quibus, iuxta certioris fidei scriptorum traditionem describuntur, Omniu[m] habitabilis orbis partiu[m] situs, propriaeq[ue] dotes. Basileae: Henrichum Petri, 1552; OLAUS MAGNUS. Historia de gentibvs septentrionalibvs. Romae: Joannes Maria de Viottis, 1555.

104 Vide também GEORGE, W. Animals on maps. London: Secker and Warburg, 1969; LISTER, R. How to identify old maps and globes, with a list of cartographers, engravers, publishers and printers concerned with printed maps and globes from c. 1500 to c. 1800. London: G. Bell and Sons, 1965.

105 Olaus Magnus in BJøRNB0, A. A. Cartographia Groenlandica. Dansk Polarcenter: København, 1912; LYNAM, E. The Carta Marina of Olaus Magnus, Venice 1539 and Rome 1572. Jenkintown: Tall Tree Library, 1949.

106 Vide KAPPLER, C. Monstres, démons et merveilles à la fin du Moyen Age. Paris: Éditions Payot, 1999.

107 PARÉ, A. Les Oevvres d'Ambroise Paré, Conseiller, et Premier Chirvrgien du Roy. Paris: Gabriel Buon, 1585; THEVET, A. Cosmographie Vniverselle d'André Thevet Cosmographe dv Roy. Paris: Pierre l'Huillier, 1575. 
o interesse de vários cartógrafos, tendo aparecido em alguns mapas do final do século XVI como o "Brasilia et Peruvia" de Cornelis de Jode (Fig. 14). Alcançando apenas 25x20 mm, a precária gravura de Jodocus Hondius não permite maiores comparações, podendo constituir a imagem especular de qualquer uma das estampas consideradas ${ }^{108}$.

Oscilando entre 56×33 mm e 27x26 mm, os cinco navios europeus representados na "America" oferecem muito poucos detalhes para análise, embora alguns pareçam ostentar a velha bandeira tricolor holandesa ou um dos antigos pavilhões espanhóis em seus mastros, tipo de minúcia bastante freqüente em diversas publicações da época ${ }^{109}$. No entanto, as ilustrações de Jodocus Hondius revelam-se de difícil avaliação pelo tamanho reduzido, rusticidade e equívocos cometidos, havendo até mesmo o caso de um vaso com velas enfunadas em posição contrária (Fig. 15). Problemas dessa natureza, infelizmente, parecem constituir um sério obstáculo para a identificação das numerosas embarcações retratadas nos mapas dos séculos XVI e XVII, circunstância lamentável face à importância de estudos desse tipo no estabelecimento da origem e do período de diversas cartas geográficas $^{110}$.

\section{Discussão}

Contrariando certas opiniões correntes ${ }^{111}$, os resultados obtidos demonstram que Jodocus Hondius não se baseou apenas nas "Grand Voyages" para compor os vários elementos

108 Ou seja: DE JODE, C. Speculum Orbis Terrae. Antverpiae: Arnoldus Coninx, 1593; PARÉ, A. Les Oevvres d'Ambroise Paré, Conseiller, et Premier Chirvrgien du Roy. Paris: Gabriel Buon, 1585; THEVET, A. Cosmographie Vniverselle d'André Thevet Cosmographe dv Roy. Paris: Pierre l'Huillier, 1575.

109 Por exemplo LINSCHOTEN, J. H. van. Itinerario, Voyage ofter schipvaert van Jan Huygen van Linschoten naer Oost ofte Portugaels Indien. Amstelredam: Cornelis Claesz, 1596; DE BRY, T. Americae Nona \& postrema Pars. Qva de ratione elementorvm: de Novi Orbis natvra: de hvivs incolarvm svperstitiosis cultibus: deq'; forma Politiae ac Reipubl. ipsorum copiosè pertractatur. Francoforti ad Moenum: Matth[aus] Beckervm, 1602.

110 LISTER, R. How to identify old maps and globes, with a list of cartographers, engravers, publishers and printers concerned with printed maps and globes from c. 1500 to c. 1800. London: G. Bell and Sons, 1965.

111 Por exemplo BURDEN, P. D. The mapping of North America: a list of printed maps 1511-1670. Rickmansworth: Raleigh Publications, 1966. 
decorativos encontrados na "America". Com efeito, malgrado essa coletânea de viagens ocupe um lugar de destaque entre as referências utilizadas, salta aos olhos a influência exercida por outras publicações do século XVI, tais como a "Cosmographie Universelle" de André Thevet ${ }^{112}$ e o relato de Dionyse Settle sobre a viagem do capitão Martin Frobischer ${ }^{113}$. Entretanto, determinar a origem exata de alguns elementos muitas vezes se revela uma tarefa sobremodo ingrata, havendo casos tanto de imagens virtualmente idênticas em duas fontes possíveis quanto de figuras que parecem constituir autênticos mosaicos elaborados a partir de mais de um original - situações opostas exemplificadas, respectivamente, pela canoa algonquina e pela piroga alakaluf. Outra séria dificuldade reside no fato de alguns motivos empregados por Hondius também estarem presentes nos trabalhos de vários outros cartógrafos da época, costume que lhe valeria a pecha de plagiador e oportunista atribuída por determinados autores ${ }^{114}$. De fato, talvez não constitua mera coincidência que o "aloe" - peixe monstruoso do Caribe descrito na "Cosmographie Universelle" de André Thevet ${ }^{115}$ - apareça em pleno Oceano Pacífico no "Brasilia et Peruvia" de Cornelis de Jode ${ }^{116}$ e mantenha essa posição na "America" (Fig. 1 e 14).

Jodocus Hondius não hesitaria em utilizar uma dada imagem em várias oportunidades distintas, conforme atestam o peixe-voador e a canoa alakaluf retratados na "America Meridionalis", um segundo mapa do "Atlas" de Mercator-Hondius (Fig. 16). Como dignos sucessores, Henricus Hondius e Joannes Janssonius deram continuidade a essa prática, voltando a reproduzir a mesma canoa alakaluf - passados mais de trinta anos - na "Americae pars Meridionalis", uma das lâminas do "Atlas Novus" (Fig. 17). Na verdade, uma acolhida favorável

112 THEVET, A. Cosmographie Vniverselle d'André Thevet Cosmographe dv Roy. Paris: Pierre l'Huillier, 1575.

113 SETTLE, D. La navigation du capitaine Martin Forbisher Anglois ès regions de west \& Nordwest, en l'année MDLXXVII. Geneva: Anthoine Chuppin, 1578; . De Martini Forbisseri Angli nauigatione in regiones occidentis et septentrionis narratio historica, ex Gallico sermone. Noribergae: In officina Catharinae Gerlachin \& Haredum Johanis Montani, 1580.

114 Por exemplo BROWN, L. A. The story of maps. New York: Bonanza Books, 1949. 115 THEVET, A. op.cit.

116 DE JODE, C. Speculum Orbis Terrae. Antverpiae: Arnoldus Coninx, 1593. 
poderia levar a sucessivas repetições de certos detalhes por décadas a fio, hábito bem demonstrado pelas várias representações de indígenas da Terra do Fogo existentes na cartografia holandesa do século $\mathrm{XVI}^{117}$ e por elementos das pranchas de Thomas Harriot observados em mapas de Henry Abraham Chatelain datados de $1719^{118}$.

Em virtude do acúmulo de informações geográficas e talvez da própria escala utilizada, Jodocus Hondius seria obrigado a deslocar todos os elementos decorativos da "America" para fora das massas continentais, dispondo sete imagens no Atlântico (41,18\%) e dez no Pacífico (58,82\%). Tal desproporção não parece ser gratuita, podendo ter servido para preencher o grande espaço ocupado por esse oceano ou mesmo para dissimular os parcos conhecimentos do autor sobre essa parte do globo ${ }^{119}$. Nesse sentido, chama a atenção que apenas uma das doze imagens em foco - o junco japonês - tenha uma relação direta com o Pacífico, isso sem contarmos que a maior e mais evidente das figuras ali localizadas - o festejo tupinambá - diz respeito a episódios ocorridos na costa brasileira. Acima de tudo, essas particularidades parecem refletir a decisão de esquecer as conquistas ibéricas e retratar exclusivamente viagens efetuadas por nações com forte ascendência protestante, cuja presença fora do Atlântico ainda permanecia muito incipiente nos primeiros momentos do século XVII. Seguindo um fio condutor comparável ao das "Grand Voyages" 120 , a "America" talvez mereça ser entendida como um tributo à expansão das forças reformistas em sua ávida disputa pelas fabulosas riquezas do além-mar, formando um engenhoso manifesto em que insurretos holandeses dividem espaço

117 BURGHARTZ, S. Aneignungen des fremden: staunen, stereotype und zirkulation um 1600. In: HUWILER, E.; WACHTER, N. (Org.). Integrationen des widerläufigen. Münster: Lit Verlag, 2004, p. 109-137. v. 3.

118 FULLER, M. C. Voyages in print: English travel to America, 1576-1624. Cambridge: Cambridge University Press, 1995; Raleigh and Roanoke, the First English colony in America: the British Library exhibit hosted by the North Carolina Museum of History. Raleigh: America's Four Hundredth Anniversary Committee \& North Carolina Department of Cultural Resources, 1985.

119 BEAGLEHOLE, J. C. The exploration of the Pacific. London: Adam \& Charles Black, 1947.

120 Vide DUCHET, M. (Org.). L'Amérique de Théodore de Bry: une collection de voyages protestante du XVIe siècle, quatre études d' iconographie. Paris: Editions du Centre National de la Recherche Scientifique, 1987. 
com aventureiros ingleses e até mesmo mercenários alemães e huguenotes franceses, esses últimos representados pela curiosa sintese promovida por Theodore de Bry ao mesclar a viagem de Hans Staden com o testemunho do calvinista Jean de Léry. Apesar de obedecer aos onipresentes ditames estéticos e econômicos ${ }^{121}$, a construção da "America" assume certos aspectos que evocam o "caráter descritivo" das pinturas pertencentes à "Época de Ouro" da escola holandesa ${ }^{122}$, lembrando em particular as chamadas "Alegorias dos Continentes" tão apreciadas no século XVII ${ }^{123}$. Ao transportar para o seu trabalho os habitantes, maravilhas, prodígios e eventos ocorridos nas diversas partes do mundo, os cartógrafos seguiriam princípios não muito distintos daqueles observados por certos artistas, temperando a rigidez da realidade geográfica com motivos - imaginários ou não - capazes de se materializar graças a recursos das mais variadas origens. A exemplo de numerosos quadros, os antigos mapas seriam espelhos multifacetados nos quais o saber dos cosmógrafos se misturava com as notícias oriundas dos "livros de viagem", grandes iconografias, compilações diversas e até mesmo o simples relato de aventureiros, elementos que convergiam para refletir uma imagem peculiar e muitas vezes única do universo conhecido.

121 Vide ZANDVLIET, K. Mapping for money: maps, plans and topographic paintings and their role in Dutch overseas expansion during the 16th and 17th centuries. Amsterdam: Batavia Lion International, 2002.

122 ALPERS, S. The art of describing. Chicago: Chicago University Press, 1983.

123 TEIXEIRA, D. M. A “Alegoria dos continentes” de Jan van Kessel "o Velho”: uma visão seiscentista da fauna dos quatro cantos do mundo. In: Brasil Holandês. Petrópolis: Editora Index, 2002. p. 1-143. v. 3. 
Figura 1: A "America" de Jodocus Hondius, mapa pertencente à edição francesa de 1619 do "Atlas" de Mercator-Hondius (Coleção de Arte ABN AMRO REAL, São Paulo).

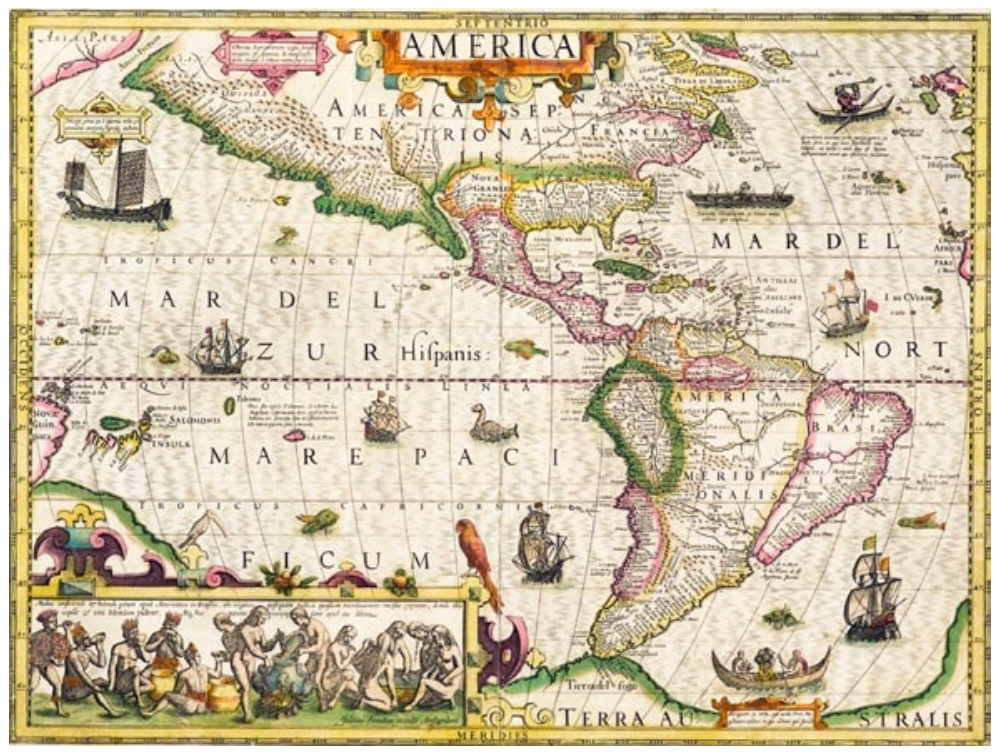


Figura 2: 0 caiaque esquimó representado na "America" de Jodocus Hondius (a); esquimós retratados na "Martini Forbisseri Angli navigatione in regiones occidentis et septentrionis" de D. Settle (1580) (b) e na "Nieuwe en Onbekende Weereld" de A. Montanus (1671)(c); aspecto do "nuiq" figurado na "History of Greenland" de D. Crantz (1767) (d) .

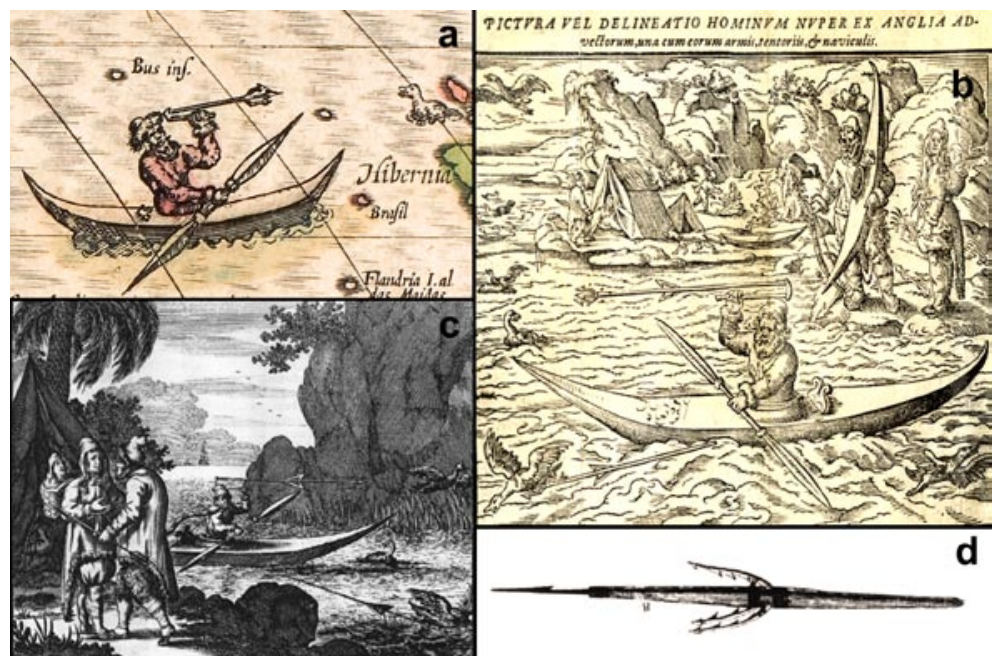


Figura 3: A canoa algonquina representada na "America" de Jodocus Hondius (a); a pescaria dos secotans segundo as ilustrações da "Briefe and true report of the new found land of Virginia" de T. Harriot (1590) (b) e da "Admiranda Narratio fida tamen, de commodis et incolarum ritibus Virginiae" de Theodore de Bry (1590) (c); a técnica utilizada pelos secotans na construção de canoas segundo a "Admiranda Narratio fida tamen, de commodis et incolarum ritibus Virginiae" de Theodore de Bry (1590) (d).

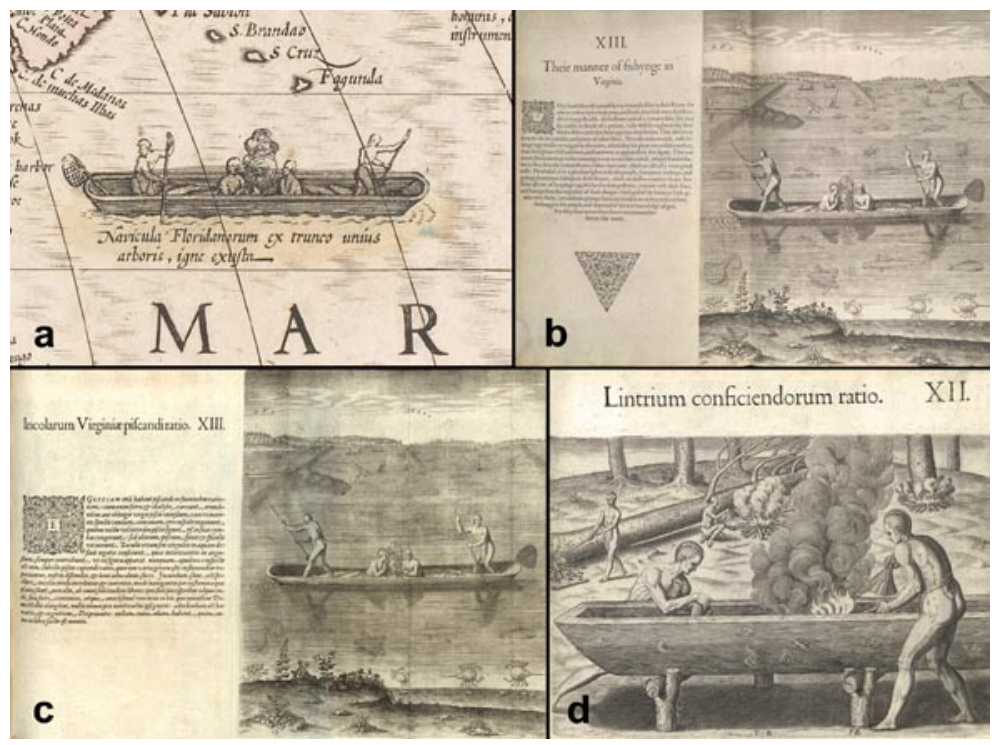


Figura 4: A canoa alakaluf representada na "America" de Jodocus Hondius (a); os habitantes da Terra do Fogo retratados no "Wijdtloopigh Verhael van 'tgene de vijf Schepen" de B.J. Potgieter (1600) (b/c) e na "Americae Nona \&t postrema Pars" de T. de Bry (1602) (d/e); um indigena da Terra do Fogo segundo o "Dracht-Thoneel" de Z. Heyns (1601) (f).

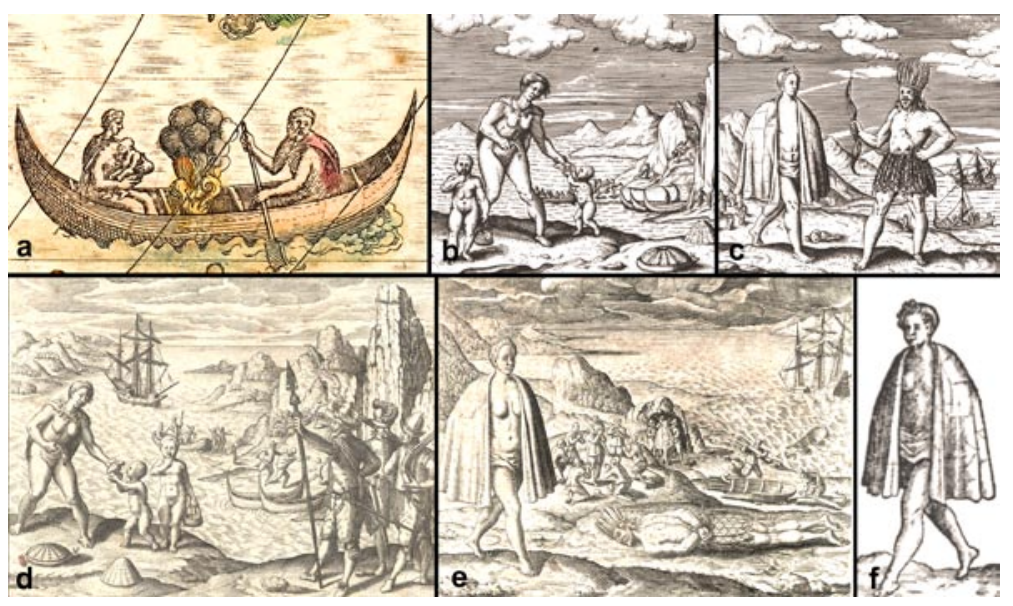

Figura 5: As canoas alakaluf representadas no "Wijdtloopigh Verhael van 'tgene de vijf Schepen" de B.J. Potgieter (1600) (a) e na "Americae Nona Et postrema Pars" de T. de Bry (1602) (b), a qual retrata uma das escaramuças travadas entre os navegadores holandeses e os habitantes da Terra do Fogo.

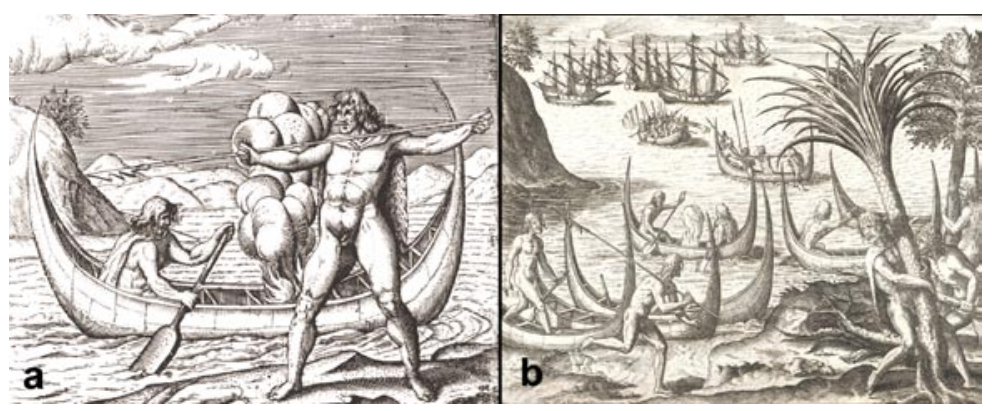


Figura 6: Representações de um junco japonês existentes na "America" de Jodocus Hondius (a); na "Beschryvinghe van de Voyagie om den geheelen Werelt Cloot" de 0. van Noort (1602) (b) e na "Americae Nona \&t postrema Pars" de T. de Bry (1602) (c); o junco chinês ou javanês figurado no "Itinerario" de J.H. van Linschoten (1596) (d), compare a legenda anexa com aquela da "America" de Jodocus Hondius.

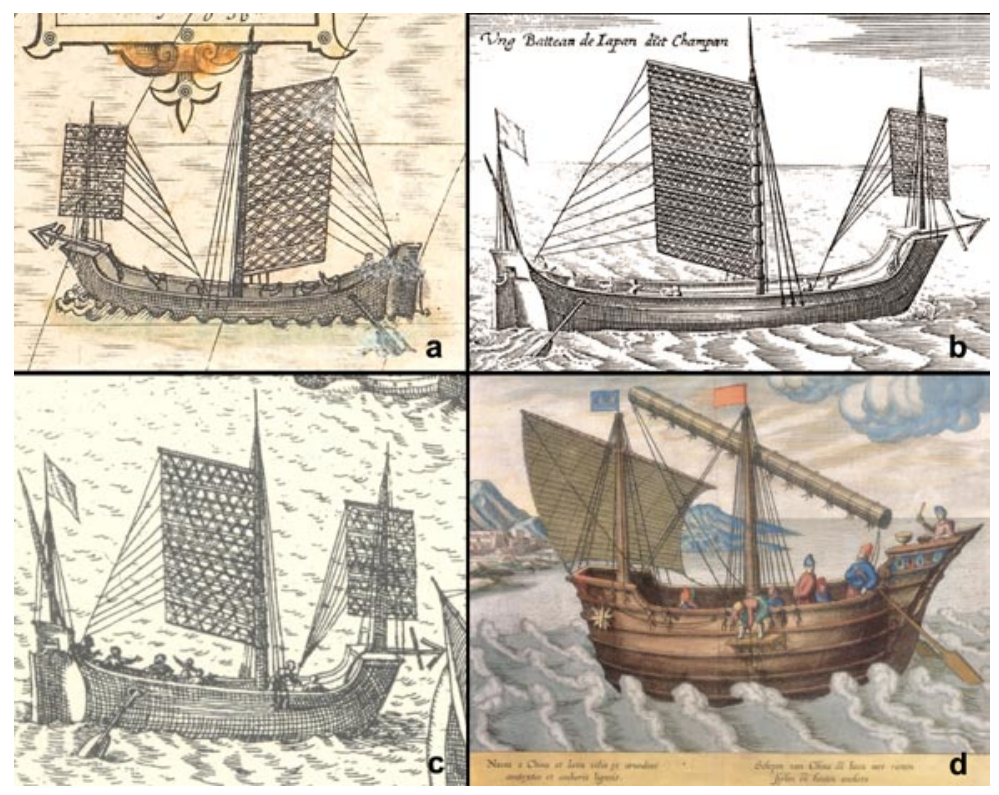


Figura 7: 0 festim tupinambá representado na "America" de Jodocus Hondius (a) e na "Americae Tertia Pars" de T. de Bry (1592) (b); muIheres preparando cauim segundo ilustração das "Singularitez de la France Antarctique" de A. Thevet (1557) (c).

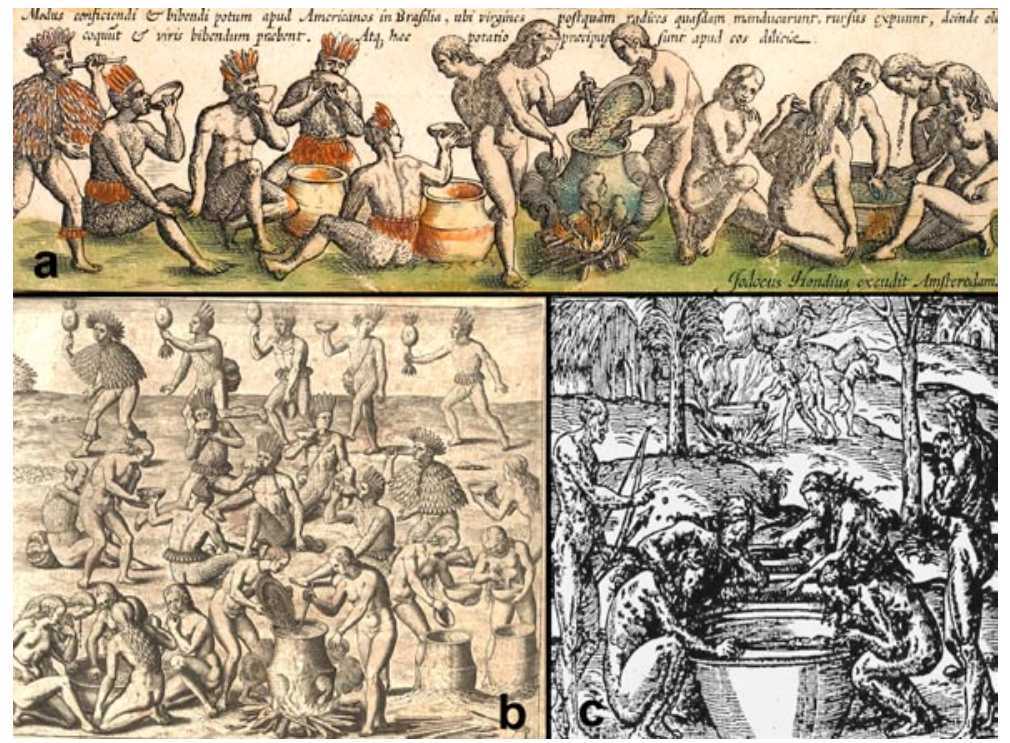


Figura 8: 0 festim tupinambá retratado na "Warhaftige Historia" de H. Staden (1557).

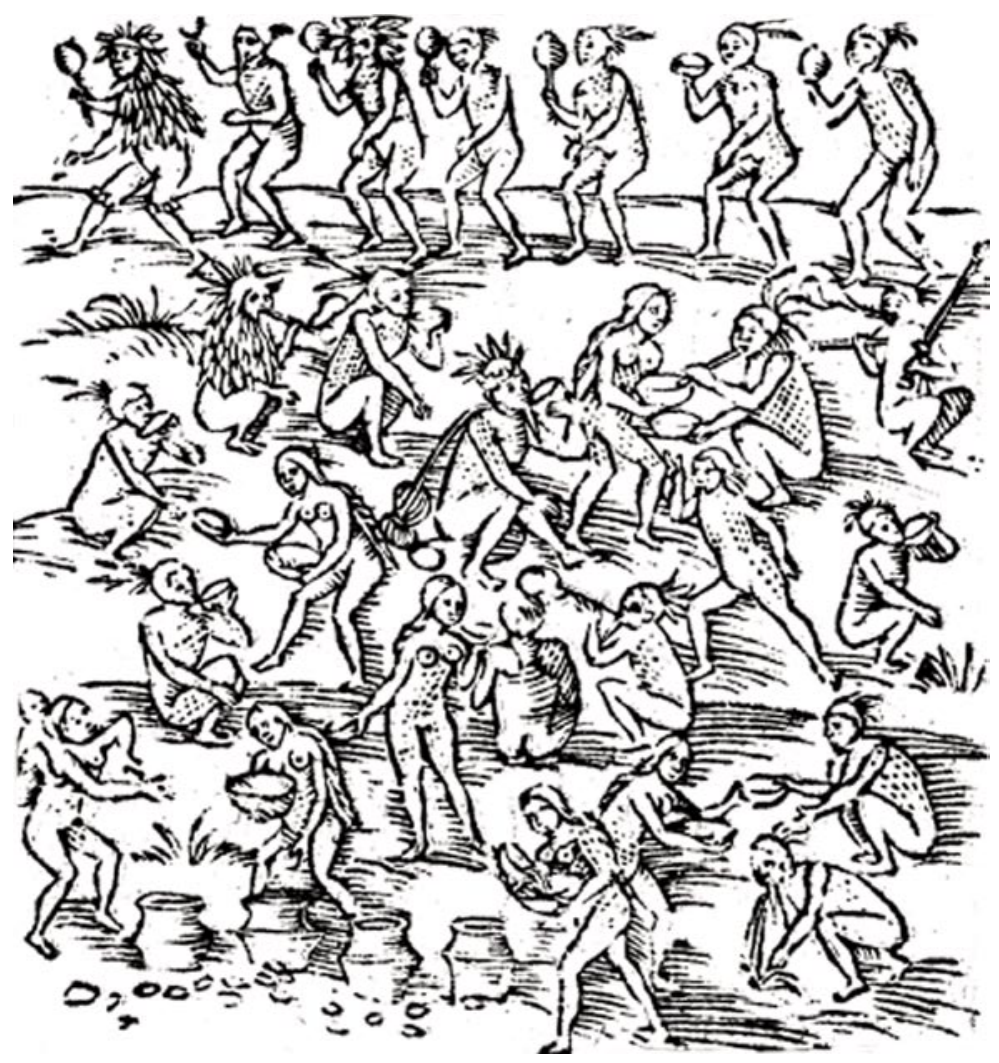


Figura 9: As araras (Psittacidae) representadas na "America" de Jodocus Hondius (a) e na "Americae Tertia Pars" de T. de Bry (1592) (b); os tucanos (Ramphastidae) retratados na "America" de Jodocus Hondius (c) e na "Cosmographie Universelle" de A. Thevet (1575) (d).

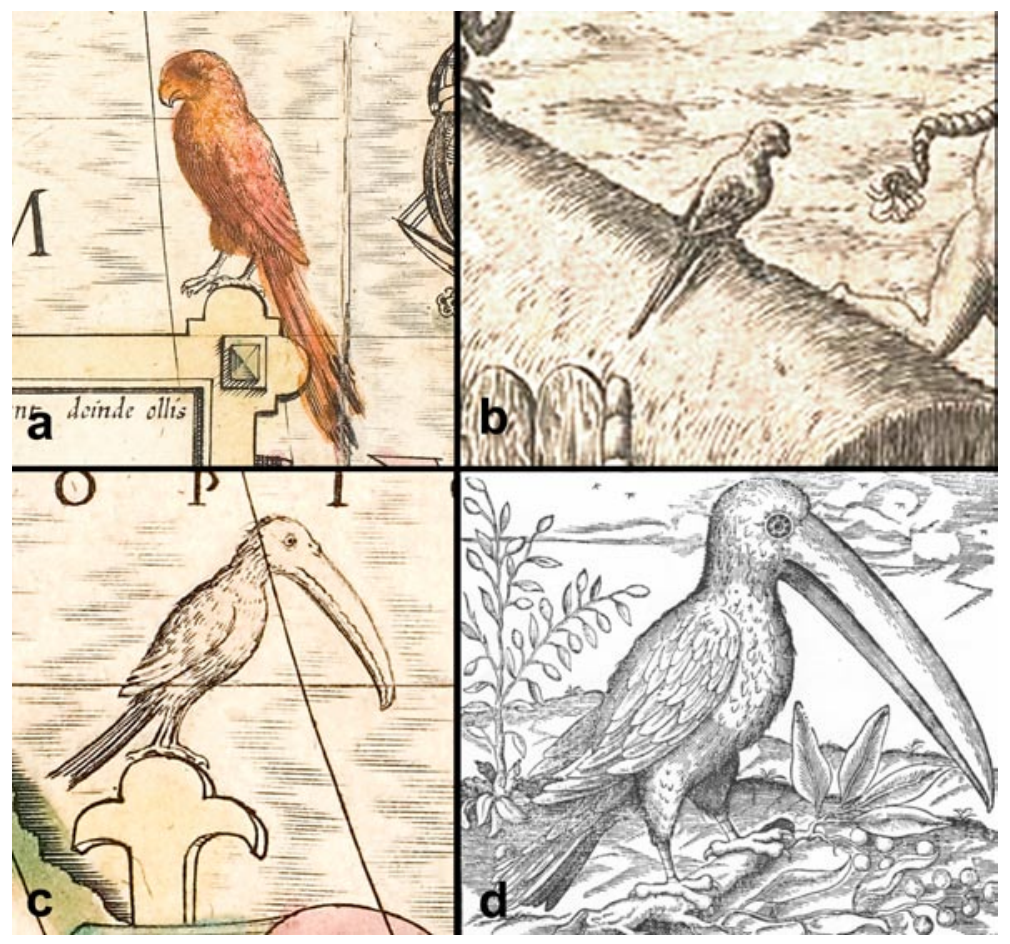


Figura 10: 0 coió (Dactylopterus volitans) (a) e os peixes-voadores (Exocoetidae) representados na "America" de Jodocus Hondius (b/c); um dos coiós retratados na "Americae Pars Quarta" de T. de Bry (1594) (d); o coió (Dactylopterus volitans) (e) e o peixe-voador (Cheilopogon heterurus) figurados no "Libri de Piscibus Marinis" de G. Rondelet (1554-1555) (f).

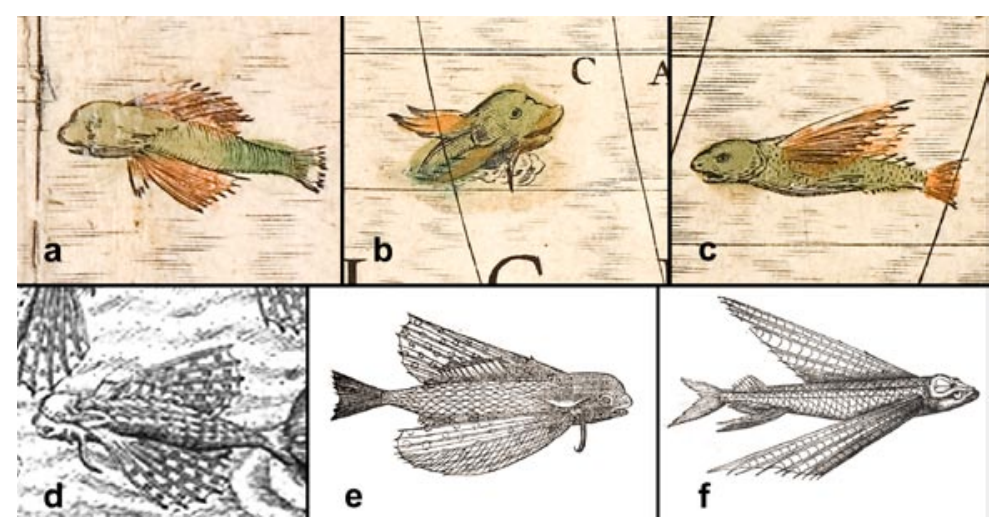

Figura 11: 0 tubarão-martelo (Sphyrna sp.) representado na "America" de Jodocus Hondius (a) e no "Libri de Piscibus Marinis" de G. Rondelet (1554-1555) (b).

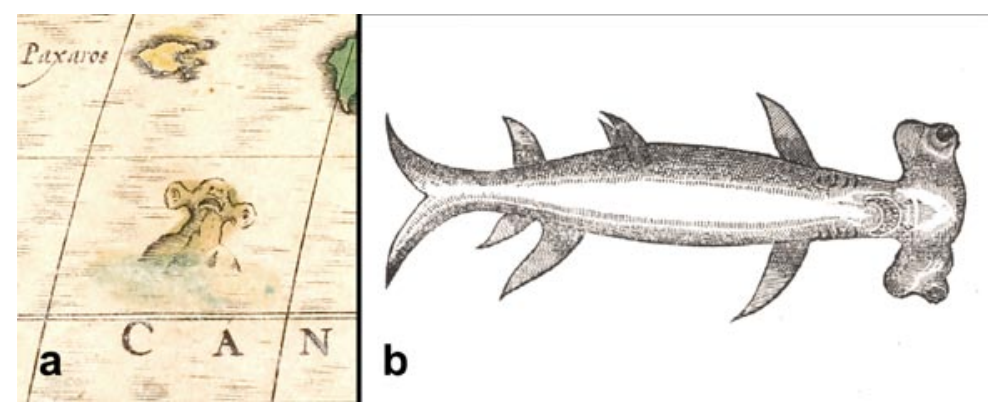


Figura 12: As baleias representadas na "America" de Jodocus Hondius (a/b) e o cetáceo monstruoso retratado na "Carta Marina" de Olaus Magnus (1539) (c); baleias e outros "monstros marinhos" dos mares boreais segundo a "Cosmographiae Universalis" de S. Münster (1552) (d).

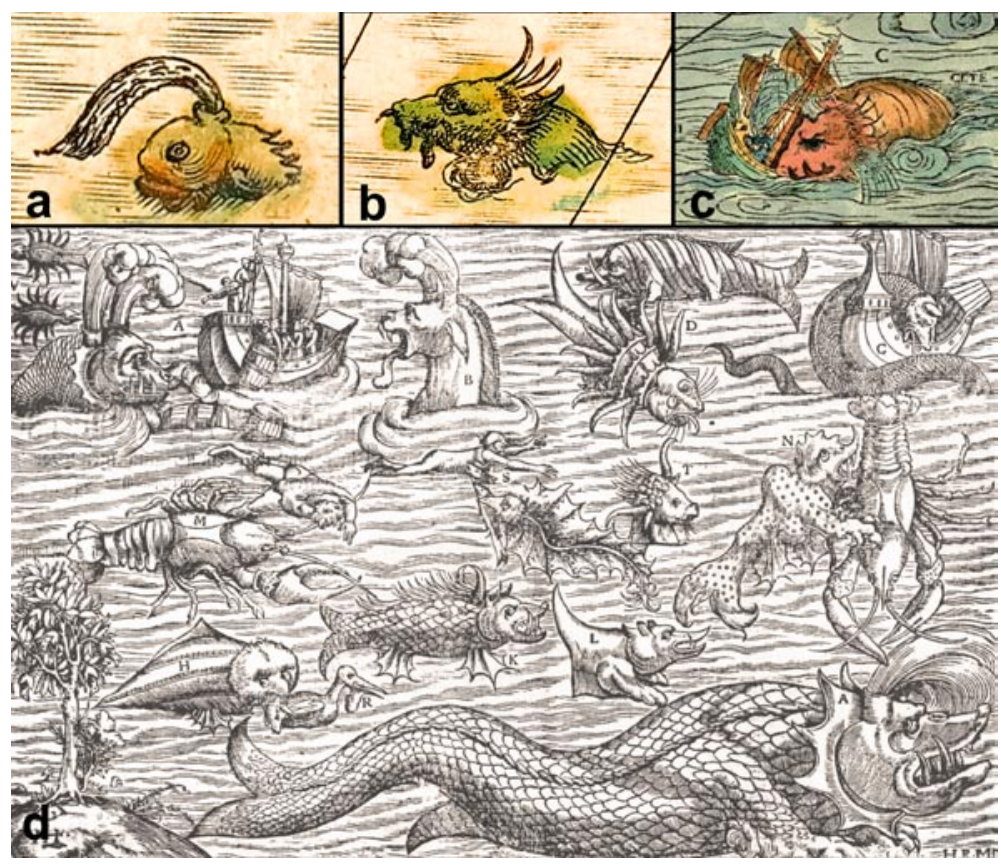

Figura 13: 0 "aloe" conforme ilustrações da "America" de Jodocus Hondius (a) e da "Cosmographie Universelle" de A. Thevet (1575) (b).

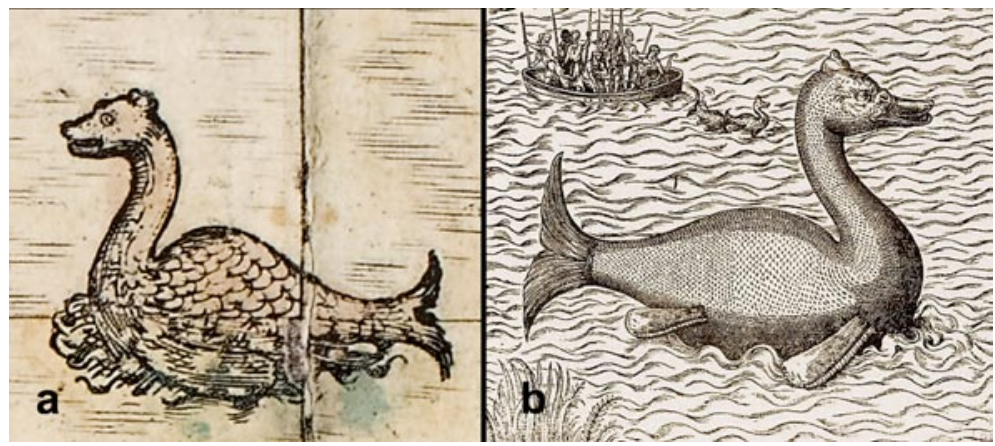


Figura 14: 0 "Brasilia et Peruvia" de Cornelis de Jode (ca. 1593) com o detalhe do monstruoso "aloe" retratado.

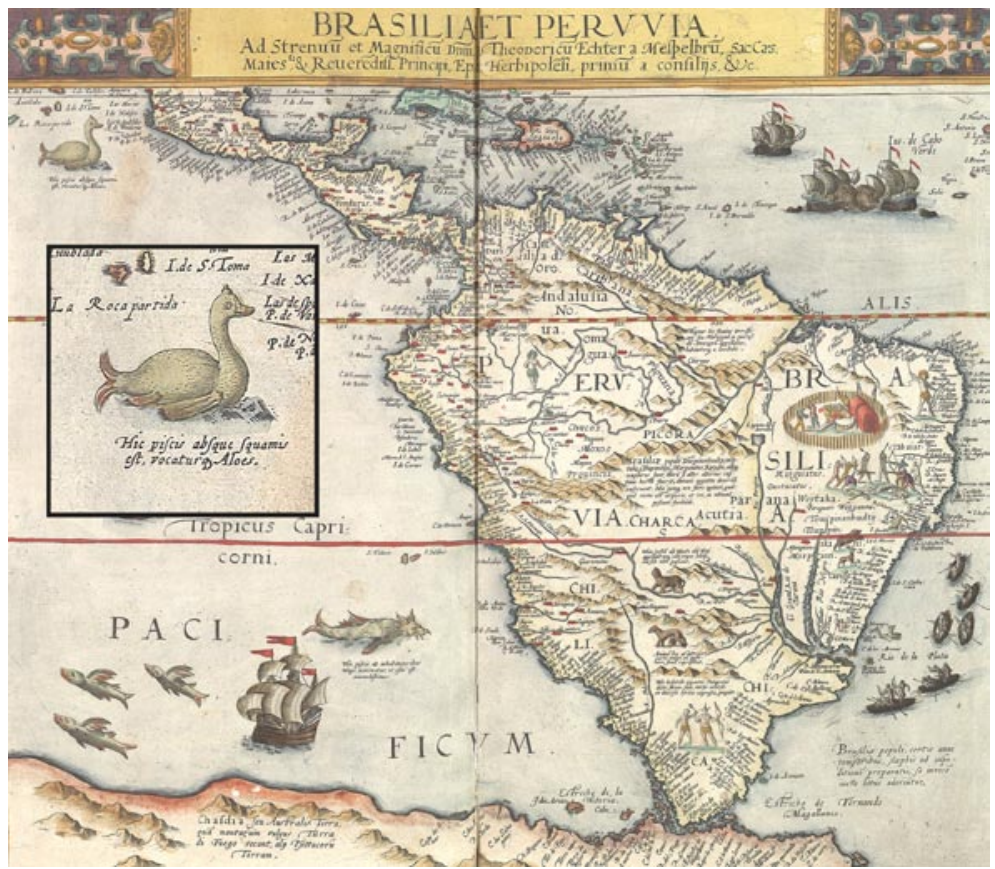


Figura 15: Uma das embarcações européias representadas na "America" de Jodocus Hondius.

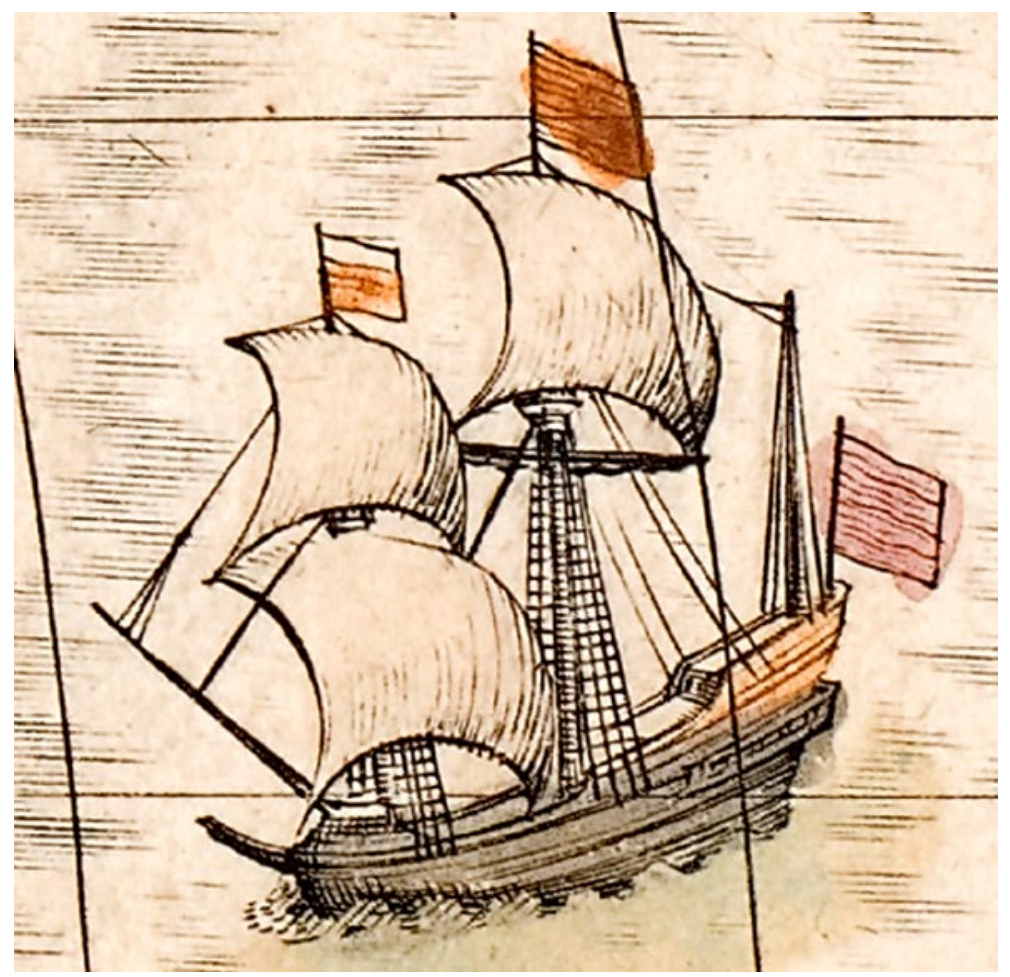


Figura 16: A "America Meridionalis" de Jodocus Hondius (1606) com detalhes da canoa alakaluf e do peixe-voador (Exocoetidae) representados (Coleção de Arte ABN AMRO REAL, São Paulo).

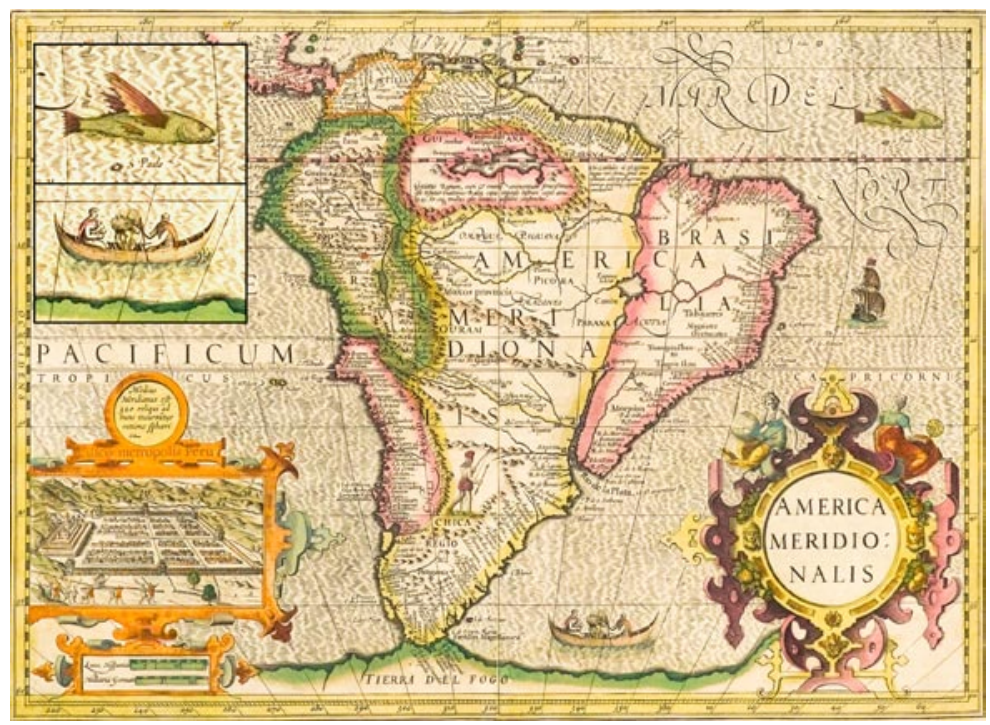


Figura 17: A "Americae pars Meridionalis" de Henricus Hondius e Joannes Janssonius (ca. 1640) com detalhe da canoa alakaluf representada (Coleção de Arte ABN AMRO REAL, São Paulo).

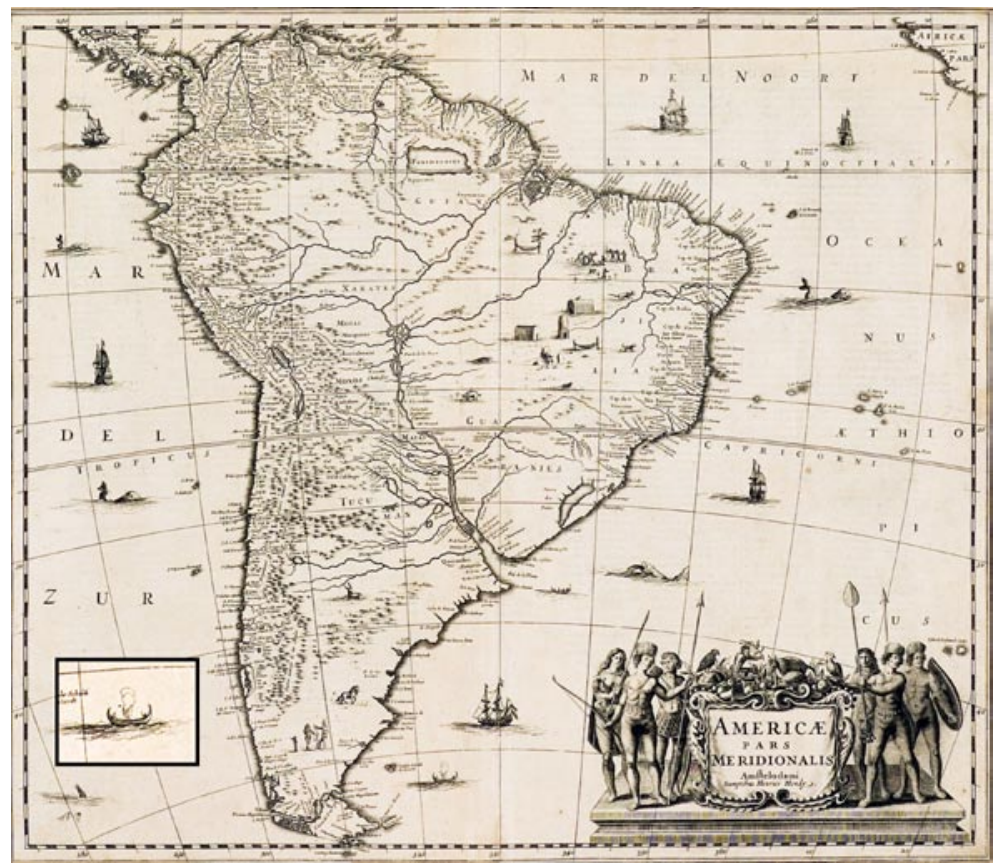

